\title{
Hygrothermal Properties of Raw Earth Materials: A Literature Review
}

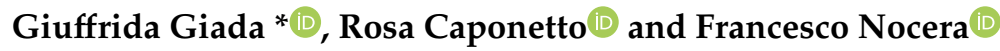 \\ Department of Civil Engineering and Architecture, University of Catania, 64 Santa Sofia Street, \\ 95125 Catania, Italy; rcapo@dau.unict.it (R.C.); francesco.nocera@unict.it (F.N.) \\ * Correspondence: giada.giuffrida@unict.it
}

Received: 2 September 2019; Accepted: 24 September 2019; Published: 27 September 2019

\begin{abstract}
Raw earth historic and contemporary architectures are renowned for their good environmental properties of recyclability and low embodied energy along the production process. Earth massive walls are universally known to be able to regulate indoor thermal and hygroscopic conditions containing energy consumptions, creating comfortable interior spaces with a low carbon footprint. Therefore, earth buildings are de facto green buildings. As a result of this, some earthen technologies have been rediscovered and implemented to be adapted to the contemporary building production sector. Nevertheless, the diffusion of contemporary earthen architecture is decelerated by the lack of broadly accepted standards on its anti-seismic and thermal performance. Indeed, the former issue has been solved using high-tensile materials inside the walls or surface reinforcements on their sides to improve their flexural strength. The latter issue is related to the penalization of earth walls thermal behavior in current regulations, which tent to evaluate only the steady-state performance of building components, neglecting the benefit of heat storage and hygrothermal buffering effect provided by massive and porous envelopes as raw earth ones. In this paper, we show the results of a paper review concerning the hygrothermal performance of earthen materials for contemporary housing: great attention is given to the base materials which are used (inorganic soils, natural fibers, and mineral or recycled aggregates, chemical stabilizers), manufacturing procedures (when described), performed tests and final performances. Different earth techniques (adobe, cob, extruded bricks, rammed earth, compressed earth blocks, light earth) have been considered in order to highlight that earth material can act both as a conductive and insulating meterial depending on how it is implemented, adapting to several climate contests. The paper aims to summarize current progress in the improvement of thermal performance of raw earth traditional mixes, discuss the suitability of existing measurement protocols for hygroscopic and natural materials and provide guidance for further researches.
\end{abstract}

Keywords: sustainable architecture; green buildings; raw earth constructions; hygrothermal characterization

\section{Introduction}

Current methods of assessing the quality and environmental impact of contemporary built environment tend to underline the importance of energy consumption and emission of pollutants that buildings cause during their period of use. The Global Status report (2018) shows that the construction sector is responsible for $36 \%$ of final energy consumption and $40 \%$ of carbon dioxide emissions related to energy generation processes in 2017. It should be noted that in this report energy uses related to the transport of building materials to construction sites have been excluded. Less importance is given to the externalities related to the annual production of waste by the construction industry, which in 
Europe alone reaches the 33\%, as reported in the 2018 report of the Global Alliance for Building and Construction [1].

The reduction of the environmental impact of building materials and processes must be pursued from a supply chain perspective through environmentally sustainable production that is able to identify eco-efficient solutions, also through the adoption of new building technologies that lead to low energy consumption and low emissions at the production, management, and end-of-life stages. Traditional materials such as raw earth and natural fibers have been rediscovered, due to their low environmental impact, high recyclability, and high availability

Houben and Guillaud [2] suggest that the main features of the "raw earth architecture" are universality and diversity, as evidenced by the vernacular and monumental architectures that are spread from Latin America to Africa, from Central Europe to the Middle East. Soils used for construction were traditionally quarried near the building site and eventually mixed with sand, gravel and, natural fibers (traditionally straw, but also animal fibers) if its composition was not considered suitable for construction.

Sometimes, to improve mechanical performance and durability, the earth is stabilised with chemical binders (cement, lime, etc.) which enhance compressive strength and reduce the sensitivity of earth-based materials to water. Other times, internal high-ensile elements or surface reinforcements are used to improve the seismic performance of buildings (e.g., timber posts or beams, canes are added, meshes of different materials, knotted ropes etc.) both by improving the flexural strength of the wall and controlling displacements caused by dynamic stresses. However, this topic falls outside the framework of this paper and will not be discussed.

Over the past 30 years, many countries such as Australia, New Zealand, New Mexico, Peru, Germany, Spain, and France published several technical codes and guidelines for raw earth construction. These attempts at normalization are important because, in the absence of a fully defined science of earthen construction, they provide guidelines for the design of the basic material (giving basic information about soil grading characteristics for each technique, percentage of clay in the mixtures, mixing water content), for the evaluation of its characteristics (compressive and tensile strength, percentage of shrinkage and durability properties, like absorption and erosion caused by water), as well as outlining a series of design measures useful to avoid errors or risks to the construction (maximum spans and heights of the walls, slenderness of the load-bearing elements, arrangement of openings, reinforcements, connections between perpendicular walls). It should be noted that in these standards, big space is given to the mechanical and physical characterization of this material, while thermal one is often neglected. Questions about the assessment of raw earth materials performances are more difficult to answer because of the diversity of test procedures, which are often adapted to specific materials or external actions. This difficulty has recently led to the establishment of the RILEM technical committee TCE 274 [2] which has the mission of defining accurate, repeatable and reproducible performance-oriented testing protocols that could, in the future, be adopted as international standards.

\section{Earth-Based Materials Manufacturing Process}

Concerning traditional raw earth production, local builders experienced the difference of using more clayey soils (with clay percentages superior to $40 \%$ ), which had to be mixed with sand or natural fibers (cereal straw, wood aggregates, bast fibres, and so on) in order to prevent shrinkage or unwanted cracking in the walls and to enhance the resistance, and used this mixes adding enough water to reach a plastic state, for the manufacturing of adobe (raw earth bricks), cob and wattle and daub.

Contemporary adobe or unfired earth brick are prepared from natural cohesive soil where gravel is usually removed. Mixes are usually done adding materials as a percentage of earth material dry weight, blending material with an amount of water ranging from $15 \%$ to $35 \%$ and sprayed in order to avoid the formation of clay lumps. After that, the materials are blended together (with mechanical equipment) until the mixture is uniform. Some authors [3] suggest leaving the earth curing by the 
action of water, for period of 12 to $48 \mathrm{~h}$, to enhance the binding forces of clays. After that, bricks can be manufactured and cured in controlled conditions for a period ranging from 28 to 60 days.

More sandy-silty soils were traditionally used at a humid state to build rammed earth walls, where the material's resistance is enhanced by a compaction process implemented by the use of wooden or iron "rammers" which where dynamically dropped on the surface of thin layers of the material, of about 10-15 cm (as the amount of earth volume to be compacted is affected by the variability of manual work, building traditions and habits, and by the materials used for the "rammers", usually realized with materials available in the site).

Soil grading used for rammed earth walls depends on the traditional mixes adopted by local builders and by the final properties which must be achieved: in no-seismic countries, soil used for rammed earth usually contains a clay percentage from 5 to $35 \%$ of the material's dry weight, silts from 10 to $30 \%$, and sand percentages from 45 up to $80 \%$ [4], gravels and pebbles are often included in the mix, as they enhance durability of the surfaces [5].

In seismic countries, the coarse fraction (gravel and pebbles) is often reduced and natural fibers are added in the mixtures in order to improve their binding force, with positive effects on the compressive and tensile strength of the final material [6]. These materials are first to dry mixture and then an amount of water corresponding to the optimum moisture content [7] as defined by a Proctor Test is added, usually ranging from 5 to $15 \%$ of dry weight (several authors suggest using the Modified Proctor Test [8-10]). Some qualitative tests are available to double-check if the amount of water used is the right one (e.g., the Drop test, as for [7]). After mixed, the material can be poured inside formworks and rammed manually or through pneumatic rams, in layers with heights ranging from 10 to $15 \mathrm{~cm}$.

A third family of earth techniques is the one using an earth slurry or clay slip mixed with big amount of fibers to implement a lightweight material, with high thermal insulating performances: it is usually known as straw-earth, light earth or lightweight straw loam in western countries, while in Latin America it's called paja-barro or tierra alivianada. Volhard [11] and Minke [3] among the others, explain that contemporary light-earth is usually prepared to mix the natural fibers with the earth slurry (a viscous liquid composed by water and smaller particles of earth, with diameters smaller than $0.5-2 \mathrm{~cm}$ ), handy or electrically mixed (with agitators or compulsory mixers), and finally left soaking as to activate the bonding properties of the clay particles. Sometimes, liquifying agents (deflocculants) as sodium carbonate, water glass, ulmic acid, or tannic acid are used to reduce the amount of water required, so to decrease the shrinkage issue and the drying time [3].

It is interesting to point out that similar techniques have been developed with small but substantial differences depending on the contest: so, for instance, European or North African Rammed Earth building have been using chemical lime stabilization historically, while Latin American ones have preferred the use of natural local fibers in order to fight shrinkage. The progress of contemporary technology has made it possible for natural soils to be modified depending on their use through an engineering process $[3,10]$ of the base material that, properly stabilised and/or additivated, is able to achieve physical-mechanical characteristics that soils alone would not have achieved.

\section{Hygrothermal Properties of Earth-Based Materials and Methodologies for Their Assessment}

From a hygrothermal point of view, raw earth behaves as a thermal and hygrometric regulator that slows and attenuates heat waves and stabilizes indoor relative humidity faster than other building materials [3], creating comfortable interiors historically described as "cool in summer and warm in winter" [12]. This description tends to simplify the physical and technical behaviour of a massive porous material in which coupled hygrothermal mechanisms coexist at a microstructural scale and depending by the pore network geometry, as fully explained by Fabbri and Morel [13]:

- a heat transmission mechanism for materials with a high thermal mass, which means high thermal inertia and heat storage,

- a phenomenon of evaporation and condensation inside the pores of the material as a result of temperature changes caused by the passage of the thermal wave: raw earth behaves as a low-tech 
phase change material where evaporation (which is an endothermic process) takes latent heat from the atmosphere during hot times and condensation (exothermic process) releases latent heat during cool times,

- a transfer of water vapour through the thickness of the wall due to the gradient of humidity between the inside and outside: the open network nanopores in earth materials facilitates absorption/release of moisture depending on the current ambient humidity,

- cooling of the wall caused by rising damp,

- $\quad$ surface overheating caused by solar radiation.

So, it is important to remark that the description of thermal performance of raw earth materials (i.e., thermal conductivity, specific heat capacity) depends on the moisture content and that calculations and simulations for earth constructions must allow for variations due to this hygrothermal behaviour. In order to test physical, mechanical and thermal characteristics sometimes the samples can be oven-dried at a temperature of $105^{\circ}$, as for [14-16] or at $50^{\circ} \mathrm{C}$ [17]. Moevus et al. [14] point out that the determination of water content in earth is of paramount importance, as it affects the mechanical (decreasing the resistance [12]) and thermal properties of earth-based materials, so that many researches [16-22] pointed out the importance of determining the equilibrium soil moisture at ambient humidity and to compare it to relative humidity, environmental temperature, effects of soil grading, surface impermeability and activity of the clay (which is the affinity of clay to water, higher for swelling clays as montmorillonite).

A constant absorption and desorption of water molecules occur when a hygroscopic material is placed in the air, depending on the environmental relative humidity and temperature. As in [14], in standard environmental conditions of temperature, pressure and relative humidity (not exceeding the $70 \%$ ) the Equilibrium moisture content (from now on EMC), which is the condition when an equal amount of absorbed and desorbed water molecules are exchanged by the material, in earth envelopes varies between the $0.5 \%$ and $7 \%$. These values changes when earth is stabilised with natural fibers (EMC increases) or chemical binders (EMC decreases). High water retention capacity of earthen materials depends on the porous and microporous structure of the soils and on the physical and chemical affinity between clays and water $[13,23]$. Moisture contents above $18 \%$ can increase the growth of fungis in earthen materials, especially when stabilised with natural fibers [18]. A complete explanation of the hygric behaviour of raw earth materials in its three saturation domains (hygroscopic, capillary, and gravity ones) can be found in $[13,23]$.

EMC can be assessed by the construction of sorption-desorption curves, by a static method or a dynamic gravimetric technique. The static method consists in the moistening of air using salts solutions, while the dynamic technique is the dynamic vapour sorption (also known as DVS method), where conditioning units maintain temperature constant while moving and moistening air in successive stages from 0 to $95 \%$, in steps of $10 \%$. The DIN EN ISO 12271 [24] regulates the first procedure. Samples are placed in boxes containing different saturated salt solutions, put in a climate chamber at various temperatures and humidity levels. Then, after three to four weeks, samples are deemed to have reached the EMC and this is obtained as a percentage of moist sample weight on the dry one, using the well-known Equation (1):

$$
\mathrm{EMC}=\frac{\left(\mathrm{W}_{\mathrm{m}}-\mathrm{W}_{\mathrm{d}}\right) * 100}{\mathrm{~W}_{\mathrm{d}}}
$$

where $W_{m}$ and $W_{d}$ are the moist and dry weight of the sample, respectively.

Vapour diffusion or Water vapour permeability $\pi$, is the capacity of exchanging moisture through the external and internal envelope of the buildings, is usually interpreted through the evaluation of the resistance factor to water vapour diffusion, $\mu$, defined as the ratio between the water vapour permeability of air and that of the earth material: literature shows that the resistance factor to water vapour $\mu$ decreases as the relative humidity increase, and it is usually ranging between 5 and 13 [14,25]. Water vapour permeability measurement, according to EN ISO 1015-19 [26], can be realized using the 
dry or wet cup method. Specimens are sealed at the top of a glass container filled with water and $1 \mathrm{~cm}$ air layer. If the measure is to be done at different relative humidity values, saturated salt solutions can be used, or the sample can be conditioned inside a climate chamber. The containers are put in a controlled room at $20 \pm 2{ }^{\circ} \mathrm{C}$ and $50 \% \mathrm{RH}$. Due to the difference in partial vapour pressure inside the cup and in the moisten environment, the mass of the cup varies because of the flow of water vapour. Finally, containers are weighted at regular time steps and mass values are plotted depending on time: equilibrium is deemed to be achieved when three values are on the same line, so the amount of water vapour passing through the sample in the unit of time is constant. Materials with higher water vapour permeability have poor vapour resistance coefficient and vice versa, materials characterised by a high $\mu$-value are impervious for water vapour passage.

Liquid water permeability is defined as the product between the intrinsic permeability and the relative permeability coefficient [27]. This can be measured with an oedometer using the variable hydraulic load method, as described by the French Standard NF X 30-442 [28]. Alternatively, absorption experiments can be used, like the Initial Rate of Suction (IRS), ruled by the British Standard BS 3921 [29], where sample is submerged in a $3 \mathrm{~mm}$ batten of water for $1 \mathrm{~min}$, or by the determination of the A-value (as for the EN ISO 1015-18 [30]), which expresses the amount of water absorbed depending on the surface of contact and the immersion time.

Finally, the hygroscopic buffering potential of earth materials can be assessed through the determination of maximal absorption value and moisture buffering value (MBV). The maximal absorption value is defined in [27] as a measurement of earth sample mass, initially stabilised at $50 \%$ $\mathrm{RH}$, after $12 \mathrm{~h}$ at a relative humidity of $80 \%$. The MBV method consists of measures of mass variation caused by moistening cycles, per unit of surface, and was defined for the first time in the NORDTEST project [31].

Massive materials as earth-based ones show high thermal inertia, which enables walls in attenuating and shifting heat passing through the envelope. It is mainly described by the evaluation of earth's volumetric heat capacity $C\left(\mathrm{~J} \mathrm{~m}^{-3} \mathrm{~K}^{-1}\right)$, defined as the product of specific heat capacity $c\left(\mathrm{~J} \mathrm{~K}^{-1}\right.$ $\mathrm{kg}^{-1}$ ) and $\rho\left(\mathrm{kg} \mathrm{m}^{-3}\right)$, mass density of earth.

$$
C=c \rho
$$

Another useful parameter is the thermal diffusivity $a\left(\mathrm{~m}^{2} \mathrm{~s}^{-1}\right)$ which is a material-specific property which characterizes the speed at which a thermal excitation moves through the material in case of unsteady heat conduction. A high thermal diffusivity corresponds to a fast propagation of the temperature excitation. The thermal diffusivity is related to the thermal conductivity $\lambda\left(\mathrm{W} \mathrm{m}^{-1} \mathrm{~K}^{-1}\right)$, specific heat capacity and density and defined as:

$$
a=\frac{\lambda}{c \rho}
$$

The thermal diffusivity of a material can be either calculated from known technical properties, or directly measured, e.g., by using the non-destructive flash method on a small specimen. Specific heat capacity can be found using an adiabatic calorimeter: the samples are cured at a high temperature and low $\mathrm{RH} \%$. The specimens are put into colder water and a couple of thermocouples placed inside the calorimeter measure the evolution of the temperature of the water until the system reaches the equilibrium. As the calorimeter is adiabatic, a specific formula is implemented in order to find the specific heat of the material, deduced from temperature, mass and specific heat capacities of water, mass and specific heat capacity of the calorimeter, temperature of the sample and equilibrium temperature:

$$
c_{p, \text { mat }}=\frac{\left(m_{\text {calo }} * c_{p, \text { calo }}+m_{w} * c_{p, w}\right) *\left(T_{e q}-T_{1}\right)}{m_{\text {mat }} *\left(T_{2}-T_{e q}\right)}
$$


where $m_{\text {calo }}, \mathrm{m}_{\mathrm{w}}$ and $m_{\text {mat }}$ are the masses of the calorimeter, the water and the material respectively, $T_{2}$ and $T_{1}$ are the sample temperature and water temperature, and $T_{e q}$ is the temperature of the system once the equilibrium is reached. Finally, $c_{p, c a l o}$ and $c_{p, w}$ are the specific heat capacity of the calorimeter and water.

Specific heat capacity and thermal diffusivity can also be measured using a Desprotherm device, asymmetric hot plate equipment where two plates of a known insulating material are placed on the sides of the specimens. In this case the specimens must have the same dimensions of the heating resistor. Finally, heat capacity can be also determined with an indirect method, using a guarded hot plate apparatus, imposing different thermal stresses, enabling the sample to store an amount of internal energy $Q$, and calculating the integral of the difference of flows from the initial temperature state, to the final one [32]. For effusivity assessment, samples must be thick enough because heat flow does not have to pass through it, as the measure is done in front of the sample under the hypothesis of semi-infiniteness of the material. For heat capacity assessment, the measurement is done on the opposite side of the heated one, so the sample must be thin enough for heat to cross it. The two methods have proved to be quite uniform in the results [17].

Moreover, thermal diffusivity is useful to calculate the thermal phase lag $\varphi(\mathrm{s})$ which determines how long it takes for heat to go through a given thickness of a material $\mathrm{d}(\mathrm{m})$. For a sinusoidal wave, it is equal to the thickness squared divided by the thermal diffusivity.

$$
\phi=\frac{\mathrm{d}^{2}}{a}
$$

In addition, it is worth to mention the thermal effusivity $b$ or $e\left(\mathrm{~J} \mathrm{~m}^{-2} \mathrm{~K}^{-1} \mathrm{~s}^{-1 / 2}\right)$ which is a measure for the ability of an object to exchange thermal energy with its surroundings.

$$
e=\sqrt{\lambda c \rho}
$$

A high value for the thermal effusivity corresponds to a material that can easily absorb and release heat at the surface. Therefore, materials with high thermal effusivity cannot hold heat long enough because heats will quickly dissipate from its surface as soon as surrounding temperature drops. On the other hand, materials with low thermal effusivity will hold heat much longer.

Another fundamental thermal characteristic which is quite difficult to assess in earth-based materials is thermal conductivity $\lambda\left(\mathrm{W} \mathrm{m}^{-1} \mathrm{~K}^{-1}\right)$ : it describes the transport of energy (in the form of heat) through a body of mass as the result of a temperature gradient. As is well known, the lower is $\lambda$, the more the material is insulating. The fact that earth is a porous and unsaturated material, reveals that heat transfer is connected to conduction in solid, liquid and gas phases (air), convection, radiation, and evaporation/condensation [13]. So, the ordinary assessment made on other materials, for earth materials only assess the apparent conductivity: some authors like Hall and Allinson [33] have developed a new procedure to assess moisture content-dependent conductivity varying the Saturation Ratio of rammed earth samples.

Usually, thermal conductivity is measured trough the hot wire apparatus [34], heat flow meter (HFM) or guarded hot plate (GHP) [35]. The first one uses a transient method, where a wire is heated and ideally extended through the centre of a homogeneous cylindrical and endless sample, and allow to heat up under constant power, so the temperature of the wire rises at exponential rate during time. The hot and cold plates, necessary to cause the heat flow, are the boundary conditions which maintain constant the temperature, so that, if thermal contact between the wire and the sample is maintained, one-dimensional heat flow can pass through the sample. The meter registers the rate at which the wire warms up, and so thermal conductivity can be derived directly, using a Fourier equation, from the resulting change in temperature detected by a sensor in contact with the test material. The hot wire must be totally embedded in the sample so that no edge effect can affect the measure. 
The heat flow meter or guarded hot plate equipment work in a similar way and in steady-state conditions, but slab sample of maximum size of $300 \times 300 \mathrm{~mm}$ (the thickness depends on the expected conductivity of the sample: more insulating material can be thicker than conductive ones because heat flow is easier) have to be prepared, with a thin capping layer which regularize the surface, realizing the hypothesis of perfect thermal contact. In this case, a downward vertical heat flow takes place between the temperature-controlled hot and cold plates. Different thermal steps can be set, changing the temperature variation, and the average temperature. As Hall and Allinson [33] a steady-state measurement of thermal conductivity for rammed earth slabs is usually reached in $7 \mathrm{~h}$ for $3 \%$ stability, and $10 \mathrm{~h}$ for $1 \%$ stability (acceptable percentage variations).

This measure can be done both for oven-dried sample (in this case measuring the dry conductivity of the material) and for moist sample, but in this case, it will explain the variation of $\lambda$ value varying the saturation rate. This procedure is rarer to be found in the literature: Hall and Allinson [33] sprayed the slabs with distilled water, and then closed them in a membrane, allowing the distribution of moisture inside the sample for $48 \mathrm{~h}$. In this case, the unsaturated slabs inside the heat flow meter are crossed by moisture transfer, which evaporated at the hot plate and condensate at the cold plate. The same measurement is repeated at different saturation ratio, $\mathrm{Sr}$, until the slab is totally saturated, and different $\lambda$ are assessed.

In the following paragraphs, we will provide a review of the main hygrothermal characteristics values found in the literature. In Table 1 are reported examples of equipment for thermophysical assessments in the market.

Table 1. Examples of equipment for thermophysical assessments in the market.

\begin{tabular}{|c|c|c|c|c|c|}
\hline $\begin{array}{c}\text { Thermophysical } \\
\text { Characteristic }\end{array}$ & $\begin{array}{l}\text { Assessment } \\
\text { Method }\end{array}$ & $\begin{array}{l}\text { Equipment/ } \\
\text { Device }\end{array}$ & $\begin{array}{c}\text { Image of the } \\
\text { Device }\end{array}$ & Minimal Characteristics & Reference \\
\hline \multirow{3}{*}{$\begin{array}{l}\text { Equilibrium } \\
\text { Moisture Content } \\
\text { EMC }\end{array}$} & \multirow{2}{*}{$\begin{array}{l}\text { Method of } \\
\text { Saturated Salt } \\
\text { Solutions }\end{array}$} & $\begin{array}{l}\text { Precision } \\
\text { balance }\end{array}$ & & $\begin{array}{l}\text { Measurement Range: } 0-15 \mathrm{~kg} \\
\text { Resolution: } 0.5 \mathrm{~g} \text { Accuracy: } \pm 0.2 \mathrm{~g}\end{array}$ & \multirow[t]{2}{*}{$\begin{array}{c}\text { DIN EN ISO, } \\
12271 \text { [24] }\end{array}$} \\
\hline & & $\begin{array}{l}\text { Saturated salt } \\
\text { solutions }\end{array}$ & & $\begin{array}{c}\text { Usual substances used in EMC determination are } \\
\text { sodium sulfate, sodium chloride, magnesium } \\
\text { nitrate and potassium carbonate }\end{array}$ & \\
\hline & DVS Method & DVS & & - & $\begin{array}{c}\text { Fabbri et al. } \\
\text { [27] }\end{array}$ \\
\hline $\begin{array}{l}\text { Thermophysical } \\
\text { Characteristic }\end{array}$ & $\begin{array}{l}\text { Assessment } \\
\text { Method }\end{array}$ & $\begin{array}{l}\text { Equipment/ } \\
\text { Device }\end{array}$ & $\begin{array}{l}\text { Image of the } \\
\text { Device }\end{array}$ & Minimal Characteristics & Reference \\
\hline $\begin{array}{l}\text { Water vapour } \\
\text { permeability } \\
\pi\end{array}$ & $\begin{array}{l}\text { Cup Method } \\
\text { for Vapour } \\
\text { Diffusion }\end{array}$ & $\begin{array}{l}\text { Vapometer } \\
\text { Permeability } \\
\text { Cup }\end{array}$ & & $\begin{array}{c}\text { Test samples up to } 3 \mathrm{~mm}(1 / 8 \mathrm{in} .) \text { thick Diameter: } \\
63.5 \mathrm{~mm} \text { (2.5 in.) Depth: } 50.8 \mathrm{~mm}(2.0 \mathrm{in} .) \text { Weight: } \\
153.4 \mathrm{~g}\end{array}$ & $\begin{array}{c}\text { EN ISO 1015-19 } \\
{[26]}\end{array}$ \\
\hline $\begin{array}{l}\text { Liquid water } \\
\text { permeability } \\
k\end{array}$ & $\begin{array}{l}\text { Variable } \\
\text { hydraulic load } \\
\text { method }\end{array}$ & Oedometer & iii & & $\begin{array}{c}\text { NF X 30-442 } \\
{[28]}\end{array}$ \\
\hline \multirow{3}{*}{$\begin{array}{l}\text { specific heat } \\
\text { capacity } \\
\qquad c\end{array}$} & $\begin{array}{l}\text { Adiabatic } \\
\text { calorimeter }\end{array}$ & Calorimeter & & $\begin{array}{l}\text { Temperature range RT to } 500^{\circ} \mathrm{C} \\
\text { Temperature readability } 0.01 \mathrm{~K} \\
\text { Heating rate: } 0 \text { to } 5 \mathrm{~K} / \mathrm{min}\end{array}$ & $\begin{array}{c}\text { Cagnon et al. } \\
{[17]}\end{array}$ \\
\hline & Flash Method & $\begin{array}{l}\text { Light Flash } \\
\text { Apparatus }\end{array}$ & & $\begin{array}{c}\text { Measurement range: } 0.01-2000 \mathrm{~mm}^{2} / \mathrm{s} \\
\text { Accuracy: } \pm 5 \% \\
\text { Repeatability: } \pm 3 \%\end{array}$ & $\begin{array}{c}\text { Cagnon et al. } \\
\text { [17] }\end{array}$ \\
\hline & $\begin{array}{l}\text { Guarded Hot } \\
\text { Plate Method }\end{array}$ & $\begin{array}{l}\text { Guarded hot } \\
\text { plate }\end{array}$ & & & ISO 8302 [35] \\
\hline $\begin{array}{l}\text { thermal } \\
\text { diffusivity } \\
a\end{array}$ & Flash Method & $\begin{array}{l}\text { Light Flash } \\
\text { Apparatus }\end{array}$ & & $\begin{array}{c}\text { Measurement range: } 0.01-2000 \mathrm{~mm}^{2} / \mathrm{s} \\
\text { Accuracy: } \pm 3 \% \\
\text { Repeatability: } \pm 2 \%\end{array}$ & $\begin{array}{c}\text { Cagnon et al. } \\
\text { [17] }\end{array}$ \\
\hline $\begin{array}{c}\text { thermal } \\
\text { conductivity } \\
\lambda\end{array}$ & $\begin{array}{l}\text { Transient Hot } \\
\text { Wire Method }\end{array}$ & Hot wire Probe & हा) & $\begin{array}{c}\text { Accuracy: } \pm 0,5 \% \\
\text { Repeatability: } 3 \% \\
\text { Ambient Conditions/Temperature: } 5^{\circ} \text { to } 35^{\circ} \mathrm{C} \\
\text { Ambient Conditions/Humidity: } 85 \% \mathrm{RH} \text { or below } \\
\text { Measurement range: } 0.03-12 \mathrm{~W} / \mathrm{mK}\end{array}$ & $\begin{array}{c}\text { ASTM } \\
\text { D5334-14 [34] }\end{array}$ \\
\hline
\end{tabular}


Table 1. Cont.

\begin{tabular}{|c|c|c|c|c|c|}
\hline $\begin{array}{l}\text { Thermophysical } \\
\text { Characteristic }\end{array}$ & $\begin{array}{l}\text { Assessment } \\
\text { Method }\end{array}$ & $\begin{array}{l}\text { Equipment/ } \\
\text { Device }\end{array}$ & $\begin{array}{c}\text { Image of the } \\
\text { Device }\end{array}$ & Minimal Characteristics & Reference \\
\hline \multirow[t]{2}{*}{$\begin{array}{c}\text { thermal } \\
\text { conductivity } \\
\lambda\end{array}$} & $\begin{array}{c}\text { Heat Flow } \\
\text { Meter/Guarded } \\
\text { Hot Plate } \\
\text { Method }\end{array}$ & $\begin{array}{c}\text { Heat Flow } \\
\text { Meter/Guarded } \\
\text { Hot Plate }\end{array}$ & & $\begin{array}{c}\text { Measurement range: up to } 2.0 \mathrm{~W} /(\mathrm{m} \cdot \mathrm{K}) \\
\text { Accuracy: } \pm 1 \% \text { to } 2 \% \\
\text { Repeatability: } 0.5 \% \\
\text { Reproducibility: } \pm 0.5 \% \\
\text { Plate temperature range: }-30^{\circ} \mathrm{C} \text { to } 90^{\circ} \mathrm{C}\end{array}$ & ISO 8302 [35] \\
\hline & Flash Method & $\begin{array}{l}\text { Light Flash } \\
\text { Apparatus }\end{array}$ & & Measurement range: $0.1-4000 \mathrm{~W} / \mathrm{mK}$ & $\begin{array}{c}\text { Cagnon et al. } \\
\text { [17] }\end{array}$ \\
\hline
\end{tabular}

N.B. Equilibrium moisture content, water vapour permeability, specific heat capacity measurements need the use of a Climatic Chamber in order to condition the samples before testing.

\section{Main Results from Contemporary Literature}

We will now show the cutting-edge researches on the topic of hygrothermal characterization of raw earth materials. The main results will be resume in the following Tables 2 and 3, with bibliographical reference. As we will see, the research on hygrothermal functional properties is above all concerned on adobe (earth bricks) or extruded bricks, which means raw earth materials prepared at the plastic state, with mixing water percentage from 15 up to $35 \%$ by dry mass of the earth material, and which are usually moulded. Concerning the hygrothermal properties, manufacturing of cob material can be considered consistent with adobe one, and in this analysis, have been considered in the same group of scientific documents.

After that, several scientific papers have focused on the thermal and physical characterization of rammed earth and compressed earth blocks (which is a contemporary technique using the same amount of water and similar composition as rammed earth but manufactured through a static compression), with a strong focus on comparing chemically stabilised and unstabilised materials.

In the end, we find light earth material, which is not that often studied with a scientific approach, with few exceptions $[11,20,22,36]$.

\subsection{Sorption-Desorption Isotherms for the Equilibrium Moisture Content (EMC)}

Medjelekh et al. [19] conduct a characterization campaign on unfired earth bricks, constructing sorption isotherms using the gravimetric method, for the identification of the EMC. At high level of $\mathrm{RH}$, the material reaches values of 5.3\%. Cagnon et al. [17] analyse EMC of five different extruded earth bricks with different clays mineralogy by the saturated salt method and the Dynamic Vapour Sorption one, discovering consistent mass moisture contents reaching 4-6\%. Ashour et al. [18] determine the EMC of different raw earth mixes stabilized with $1 \%$ and 3\% barley or wheat straw, and $5 \%$ and $10 \%$ cement or gypsum. At high value of relative humidity, bricks without additives stabilize at EMC values of $5.35 \%\left(10{ }^{\circ} \mathrm{C}\right)$ and $4.99 \%\left(40{ }^{\circ} \mathrm{C}\right)$. Wheat straw-stabilized bricks reached EMC at $3.4-3.7 \%$ for $1 \%$ and $3 \%$ fibers percentage at $10{ }^{\circ} \mathrm{C}$, while at $40{ }^{\circ} \mathrm{C}$ they respectively stabilize at $3.2-3.3 \%$. Barley Straw-stabilized bricks reached EMC at 3.4-3.5\% for $1 \%$ and $3 \%$ fibers percentage at $10{ }^{\circ} \mathrm{C}$, while at $40{ }^{\circ} \mathrm{C}$ they respectively stabilize at 3.3-3.4\%. EMC values increase with increasing relative humidity but decrease with increasing temperature. When fibers are added to the mix, the EMC increases for all the ranges of temperature. When cement or gypsum content increase EMC decreases. Finally, Allam et al. [21] find EMC values for clay bricks ranging from 3\% to $7 \%$. 
Table 2. Earth Mix constituents.

\begin{tabular}{|c|c|c|c|c|c|c|c|c|c|}
\hline \multirow{2}{*}{$\begin{array}{l}\text { Constructive } \\
\text { Technique }\end{array}$} & \multirow{2}{*}{ Authors } & \multirow{2}{*}{ Ref. } & \multicolumn{7}{|c|}{ Earth Mix } \\
\hline & & & $\begin{array}{l}\text { Mixing Water } \\
\text { Content } w_{i}[\%]\end{array}$ & Clay [\%] & Silt [\%] & Sand [\%] & Gravel [\%] & $\begin{array}{l}\text { Type and amount of } \\
\text { Fiber }\end{array}$ & $\begin{array}{l}\text { Type and amount of } \\
\text { Chemical Stabilizer }\end{array}$ \\
\hline $\begin{array}{l}\text { Adobe/Cob/Wattle } \\
\text { and Daub }\end{array}$ & Medjelekh et al. (2017) & 23 & - & - & - & - & - & - & - \\
\hline \multirow{2}{*}{$\begin{array}{l}\text { Constructive } \\
\text { Technique }\end{array}$} & \multirow{2}{*}{ Authors } & \multirow{2}{*}{ Ref. } & \multicolumn{7}{|c|}{ Earth Mix } \\
\hline & & & $\begin{array}{l}\text { Mixing Water } \\
\text { Content } w_{i}[\%]\end{array}$ & Clay [\%] & Silt [\%] & Sand [\%] & Gravel [\%] & $\begin{array}{l}\text { Type and Amount of } \\
\text { Fiber }\end{array}$ & $\begin{array}{l}\text { Type and Amount of } \\
\text { Chemical Stabilizer }\end{array}$ \\
\hline \multirow[t]{7}{*}{$\begin{array}{l}\text { Adobe/Cob/Wattle } \\
\text { and Daub }\end{array}$} & Cagnon et al. (2014) & 20 & - & $23-38$ & $27-37$ & $33-43$ & $0-3$ & - & - \\
\hline & $\begin{array}{l}\text { Laborel-Préneron et al. } \\
\text { (2015) }\end{array}$ & 28 & $14-21$ & 20 & $80(60 \%$ & nestone) & - & Straw, $0 \%, 3 \%, 6 \%$ & - \\
\hline & El Fgaier et al. (2016) & 19 & - & 6 & $79-89$ & 5-15 & - & - & - \\
\hline & $\begin{array}{c}\text { Gomaa et al. (2019)-3d } \\
\text { printed cob }\end{array}$ & 29 & $25-26$ & 21.5 & \multicolumn{2}{|c|}{79.5} & - & Straw $2 \%$ & - \\
\hline & CobBauge Project 2018 & 29 & $28-31$ & - & - & - & - & $\begin{array}{c}\text { Hemp shiv, Chopped } \\
\text { Reed and Straw, } 0 \% \text {, } \\
2 \%, 4 \%, 8 \%\end{array}$ & - \\
\hline & Ashour, Korjenic et al. (2015) & $15-30$ & 24 & 28.7 & 63.3 & 5 & 3 & $\begin{array}{l}\text { Wheat straw, Barley } \\
\text { straw, } 0 \%, 1 \%, 3 \%\end{array}$ & $\begin{array}{c}\text { Cement, gypsum, } 0 \% \text {, } \\
5 \%, 10 \%\end{array}$ \\
\hline & Millogo et al. (2014) & 31 & 20 & 25 & 30 & 45 & - & $\begin{array}{l}\text { Hibiscus cannibinus, } \\
0 \%, 0.2 \%, 0.4 \%, 0.8 \%\end{array}$ & - \\
\hline \multirow{2}{*}{$\begin{array}{l}\text { Constructive } \\
\text { Technique }\end{array}$} & \multirow{2}{*}{ Authors } & \multirow{2}{*}{ Ref. } & \multicolumn{7}{|c|}{ Earth Mix } \\
\hline & & & $\begin{array}{l}\text { Mixing Water } \\
\text { Content } w_{i}[\%]\end{array}$ & Clay [\%] & Silt [\%] & Sand [\%] & Gravel [\%] & $\begin{array}{l}\text { Type and Amount of } \\
\text { Fiber }\end{array}$ & $\begin{array}{l}\text { Type and Amount of } \\
\text { Chemical Stabilizer }\end{array}$ \\
\hline \multirow[t]{3}{*}{$\begin{array}{l}\text { Adobe/Cob/Wattle } \\
\text { and Daub }\end{array}$} & Ouedraogo et al. (2019) & 38 & 24 & 56 & 14 & 30 & - & $\begin{array}{c}\text { Fonio straw, } 0 \%, 0.2 \% \text {, } \\
0.4 \%, 0.6 \%, 0.8 \%, 1 \%\end{array}$ & - \\
\hline & Allam et al. (2018) & 40 & - & - & - & - & - & - & - \\
\hline & $\begin{array}{c}\text { Giroudon, Laborel-Préneron, } \\
\text { et al. (2019) }\end{array}$ & 42 & $14-21$ & 50 & 38 & 12 & - & $\begin{array}{l}\text { Barley and Lavender } \\
\text { Straw, } 0 \%, 3 \%, 6 \%\end{array}$ & - \\
\hline \multirow{5}{*}{$\begin{array}{c}\text { Rammed } \\
\text { Earth/Compressed } \\
\text { Earth Block }\end{array}$} & Indekeu et al. (2017) & 24 & 10.4 & 20 & 61 & 19 & - & - & - \\
\hline & Hall \& Allison (2009) & $16-21$ & 8 & \multicolumn{2}{|c|}{30} & $0-30$ & $40-70$ & - & Cement, $6 \%$ \\
\hline & Allison \& Hall (2010) & 25 & - & \multicolumn{4}{|c|}{ Crushed ironstone quarry waste, grit sand } & - & Cement, $7 \%$ \\
\hline & Zhang Lei et al. (2018) & 32 & - & 17 & 51 & 32 & - & - & - \\
\hline & $\begin{array}{l}\text { Suárez-Domínguez et al. } \\
\text { (2018) }\end{array}$ & 26 & - & & 37 & & 63 & $\begin{array}{l}\text { Ixtle (Agave fiber) } 100 \\
\mathrm{mg} / 1 \mathrm{~kg} \text { mix }\end{array}$ & $\begin{array}{c}\text { Cement } 16 \% \text {, Nopal } \\
\text { mucilage } 1 \%\end{array}$ \\
\hline
\end{tabular}


Table 2. Cont

\begin{tabular}{|c|c|c|c|c|c|c|c|c|c|}
\hline \multirow{2}{*}{$\begin{array}{l}\text { Constructive } \\
\text { Technique }\end{array}$} & \multirow{2}{*}{ Authors } & \multirow{2}{*}{ Ref. } & \multicolumn{7}{|c|}{ Earth Mix } \\
\hline & & & $\begin{array}{l}\text { Mixing Water } \\
\text { Content } w_{i}[\%]\end{array}$ & Clay [\%] & Silt [\%] & Sand [\%] & Gravel [\%] & $\begin{array}{l}\text { Type and Amount of } \\
\text { Fiber }\end{array}$ & $\begin{array}{l}\text { Type and Amount of } \\
\text { Chemical Stabilizer }\end{array}$ \\
\hline \multirow[t]{3}{*}{$\begin{array}{l}\text { Rammed Earth/ } \\
\text { Compressed Earth } \\
\text { Block }\end{array}$} & $\begin{array}{l}\text { Barbeta Solà \& Massó Ros } \\
\text { (2015) }\end{array}$ & $33-34$ & - & 23 & 26 & 51 & - & $\begin{array}{l}\text { Black cork shavings, } \\
\text { expanded clay, } \\
\text { triturated almond shell, } \\
\text { olive stone, } 15-40 \%\end{array}$ & Cement, $5 \%, 8 \%$ \\
\hline & Soudani et al. (2017) & 35 & 18 & 16 & & 84 & & - & Lime, $2.5 \%$ \\
\hline & Porter et al. (2018) & 27 & $6.2-7.6$ & 15 & \multicolumn{2}{|c|}{65} & 20 & $\begin{array}{c}\text { Crumbed rubber } 0 \%, \\
5 \%, 10 \%, 20 \%\end{array}$ & Cement, $0 \%, 6 \%$ \\
\hline \multirow{4}{*}{ Light earth } & Cobreros et al. (2018) & 36 & - & \multicolumn{2}{|c|}{60} & 40 & - & $\begin{array}{c}\text { Barley straw: } 0 \%, 1 \%, \\
2 \% 4 \%, 8 \%\end{array}$ & $\begin{array}{c}\text { Lime, Flying Ashes: } \\
16 \%, 20 \%\end{array}$ \\
\hline & Wieser et al. (2018) & 22 & - & - & - & - & - & $\begin{array}{l}\text { Gramineae straw, Rice } \\
\text { husk, Wood chip }\end{array}$ & - \\
\hline & Minke (2006) & 4 & - & - & - & - & - & $\begin{array}{l}\text { Straw, Expanded Clay, } \\
\text { Cork shavings, Wood } \\
\text { chips }\end{array}$ & - \\
\hline & Volhard (2016) & 12 & - & - & - & - & - & Straw, Woodchip & - \\
\hline \multirow{2}{*}{$\begin{array}{l}\text { Constructive } \\
\text { Technique }\end{array}$} & \multirow{2}{*}{ Authors } & \multirow{2}{*}{ Ref. } & \multicolumn{7}{|c|}{ Earth Mix } \\
\hline & & & $\begin{array}{l}\text { Mixing Water } \\
\text { Content } w_{i}[\%]\end{array}$ & Clay [\%] & Silt [\%] & Sand $[\%]$ & Gravel [\%] & $\begin{array}{l}\text { Type and Amount of } \\
\text { Fiber }\end{array}$ & $\begin{array}{l}\text { Type and Amount of } \\
\text { Chemical Stabilizer }\end{array}$ \\
\hline \multirow[t]{2}{*}{ Light earth } & Labat, Magniont et al. (2016) & 39 & - & - & - & - & - & Straw & - \\
\hline & $\begin{array}{l}\text { Niang, Maalouf, Moussa } \\
\text { et al. (2018) }\end{array}$ & 41 & - & & 70 & & 30 & $\begin{array}{c}\text { Typha Australis 20\%, } \\
33 \%\end{array}$ & - \\
\hline
\end{tabular}


Table 3. Measured Hygrothermal Properties for different Earth-based materials.

\begin{tabular}{|c|c|c|c|c|c|c|c|c|c|}
\hline \multirow{2}{*}{$\begin{array}{l}\text { Constructive } \\
\text { Technique }\end{array}$} & \multirow{2}{*}{ Authors } & \multirow{2}{*}{ Ref. } & \multicolumn{7}{|c|}{ Measured Hygrothermal Properties } \\
\hline & & & $\begin{array}{l}\text { Dry Density } \rho \\
\quad\left[\mathrm{kg} \mathrm{m}^{-3}\right]\end{array}$ & EMC Range [\%] & $\begin{array}{c}\text { Water Vapour } \\
\text { Resistance Factor } \\
\mu[-]\end{array}$ & $\begin{array}{c}\text { Specific Heat } \\
\text { Capacity c } \\
{\left[\mathrm{J} \mathrm{kg}^{-1} \mathrm{~K}^{-1}\right]}\end{array}$ & $\begin{array}{c}\text { Thermal } \\
\text { Conductivity } \lambda \\
{\left[\mathrm{W} \mathrm{m}^{-1} \mathrm{~K}^{-1}\right]}\end{array}$ & $\begin{array}{l}\text { Thermal Effusivity e } \\
{\left[\mathrm{J} \mathrm{m}^{-2} \mathrm{~K}^{-1} \mathrm{~s}^{-1 / 2}\right]}\end{array}$ & $\begin{array}{l}\text { Thermal Diffusivity a } \\
{\left[\mathrm{m}^{2} \mathrm{~s}^{-1}\right]}\end{array}$ \\
\hline \multirow{2}{*}{$\begin{array}{l}\text { Adobe/Cob/Wattle } \\
\text { and Daub }\end{array}$} & Medjelekh et al. (2017) & 23 & $1761.9-1797.6$ & $\begin{array}{c}2-5.3 \text { Climate } \\
\text { Chamber and } \\
\text { Gravimetric } \\
\text { method }\end{array}$ & - & $\begin{array}{c}817.6\left(40^{\circ} \mathrm{C}\right)-877.6 \\
\left(100^{\circ} \mathrm{C}\right) \\
\text { Calorimeter }\end{array}$ & $\begin{array}{l}\text { 0.77-0.95 Hot disk } \\
\text { Apparatus }\end{array}$ & - & - \\
\hline & Cagnon et al. (2014) & 20 & $\begin{array}{c}1940-2070 \\
\text { oven-dried } \\
\text { samples at } 50{ }^{\circ} \mathrm{C}\end{array}$ & $\begin{array}{l}\text { 4-6 Saturated salt } \\
\text { solutions and } \\
\text { DVS methods }\end{array}$ & $\begin{array}{l}\text { 3-7 (wet), 7-9 } \\
\text { (dry) Cup Method }\end{array}$ & $\begin{array}{c}\text { 900-960 } \\
\text { Calorimeter } \\
950-1030 \\
\text { Desprotherm }\end{array}$ & $\begin{array}{c}0.47-0.59 \mathrm{GHP} \\
0.40 \text { to } 0.69 \\
\text { Desprotherm }\end{array}$ & $\begin{array}{c}900-1100 \\
\text { Desprotherm }\end{array}$ & - \\
\hline \multirow{2}{*}{$\begin{array}{l}\text { Constructive } \\
\text { Technique }\end{array}$} & \multirow{2}{*}{ Authors } & \multirow{2}{*}{ Ref. } & \multicolumn{7}{|c|}{ Measured Hygrothermal Properties } \\
\hline & & & $\begin{array}{l}\text { Dry Density } \rho \\
\quad\left[\mathrm{kg} \mathrm{m}^{-3}\right]\end{array}$ & EMC Range [\%] & $\begin{array}{c}\text { Water Vapour } \\
\text { Resistance Factor } \\
\mu[-]\end{array}$ & $\begin{array}{c}\text { Specific Heat } \\
\text { Capacity } c \\
{\left[\mathrm{~J} \mathrm{~kg}^{-1} \mathrm{~K}^{-1}\right]}\end{array}$ & $\begin{array}{c}\text { Thermal } \\
\text { Conductivity } \lambda \\
{\left[\mathrm{W} \mathrm{m}^{-1} \mathrm{~K}^{-1}\right]}\end{array}$ & $\begin{array}{l}\text { Thermal Effusivity } e \\
{\left[\mathrm{~J} \mathrm{~m}^{-2} \mathrm{~K}^{-1} \mathrm{~s}^{-1 / 2}\right]}\end{array}$ & $\begin{array}{c}\text { Thermal Diffusivity } a \\
{\left[\mathrm{~m}^{2} \mathrm{~s}^{-1}\right]}\end{array}$ \\
\hline \multirow[t]{7}{*}{$\begin{array}{l}\text { Adobe/Cob/Wattle } \\
\text { and Daub }\end{array}$} & $\begin{array}{l}\text { Laborel-Préneron et al. } \\
\qquad(2015)\end{array}$ & 28 & $\begin{array}{c}1075-1995 \\
\text { oven-dried } \\
\text { samples at } 40^{\circ} \mathrm{C} \\
\text { for } 24 \mathrm{~h}\end{array}$ & - & - & - & $0.14-0.57$ GHP & - & - \\
\hline & El Fgaier et al. (2016) & 19 & $1788-2268$ & - & - & 545-712 HFM & 0.89-0.91 HFM & $\begin{array}{c}\text { 936.49-1176.95 } \\
\text { Calculated }\end{array}$ & $\begin{array}{l}5.7210^{-7}-9.2310^{-7} \\
\text { Calculated }\end{array}$ \\
\hline & $\begin{array}{l}\text { Gomaa et al. (2019)-3d } \\
\text { printed cob }\end{array}$ & 29 & $1283.7-1780.3$ & - & - & - & $0.32-0.48 \mathrm{HFM}$ & - & - \\
\hline & CobBauge Project 2018 & 29 & $1038.7-1832.3$ & - & - & - & $0.25-0.84$ HFM & - & - \\
\hline & Ashour, Korjenic et al. (2015) & $15-30$ & $\begin{array}{c}1088.5-1575.6 \\
\text { oven-dried } \\
\text { samples at } 70^{\circ} \mathrm{C}\end{array}$ & $\begin{array}{l}\text { 1.74-7.2 Saturated } \\
\text { salt solutions }\end{array}$ & - & - & $\begin{array}{l}0.31-0.96 \text { Hot } \\
\text { wire method }\end{array}$ & - & - \\
\hline & Millogo et al. (2014) & 31 & - & - & - & - & $\begin{array}{l}1.30-1.67 \text { Hot } \\
\text { wire method }\end{array}$ & - & - \\
\hline & Ouedraogo et al. (2019) & 38 & - & - & - & - & $\begin{array}{l}0.37-1.05 \text { Hot } \\
\text { wire method }\end{array}$ & - & - \\
\hline
\end{tabular}


Table 3. Cont.

\begin{tabular}{|c|c|c|c|c|c|c|c|c|c|}
\hline \multirow{2}{*}{$\begin{array}{l}\text { Constructive } \\
\text { Technique }\end{array}$} & \multirow{2}{*}{ Authors } & \multirow{2}{*}{ Ref. } & \multicolumn{7}{|c|}{ Measured Hygrothermal Properties } \\
\hline & & & $\begin{array}{l}\text { Dry Density } \rho \\
\quad\left[\mathrm{kg} \mathrm{m}^{-3}\right]\end{array}$ & EMC Range [\%] & $\begin{array}{c}\text { Water Vapour } \\
\text { Resistance Factor } \\
\mu[-]\end{array}$ & $\begin{array}{l}\text { Specific Heat } \\
\text { Capacity c } \\
{\left[\mathrm{J} \mathrm{kg}^{-1} \mathbf{K}^{-1}\right]}\end{array}$ & $\begin{array}{c}\text { Thermal } \\
\text { Conductivity } \lambda \\
{\left[\mathrm{W} \mathrm{m}^{-1} \mathrm{~K}^{-1}\right]}\end{array}$ & $\begin{array}{l}\text { Thermal Effusivity e } \\
{\left[\mathrm{J} \mathrm{m}^{-2} \mathrm{~K}^{-1} \mathrm{~s}^{-1 / 2}\right]}\end{array}$ & $\begin{array}{l}\text { Thermal Diffusivity a } \\
{\left[\mathrm{m}^{2} \mathrm{~s}^{-1}\right]}\end{array}$ \\
\hline & Allam et al. (2018) & 40 & 1980 & $3-7$ & - & $\begin{array}{l}750 \text { (dry)- } \\
1200 \text { (wet) }\end{array}$ & $\begin{array}{l}0.38-0.43 \text { (dry), } \\
0.55-0.62 \text { (wet) }\end{array}$ & - & - \\
\hline & $\begin{array}{l}\text { Giroudon, Laborel-Préneron, } \\
\text { et al. (2019) }\end{array}$ & 42 & $\begin{array}{c}1195-1988 \\
\text { oven-dried } \\
\text { samples at } 40^{\circ} \mathrm{C} \\
\text { for } 24 \mathrm{~h} \\
\end{array}$ & - & - & - & $0.155-0.471 \mathrm{GHP}$ & - & - \\
\hline \multirow{4}{*}{$\begin{array}{c}\text { Rammed } \\
\text { Earth/Compressed } \\
\text { Earth Block }\end{array}$} & Indekeu et al. (2017) & 24 & $\begin{array}{l}1940 \text { oven-dried } \\
\text { samples at } 105^{\circ} \mathrm{C}\end{array}$ & $\begin{array}{l}9 \text { Climatic } \\
\text { chamber }\end{array}$ & - & $\begin{array}{l}939 \text { Conductivity } \\
\text { meter }\end{array}$ & $\begin{array}{c}1.1 \text { Conductivity } \\
\text { meter }\end{array}$ & - & - \\
\hline & Hall \& Allison (2009) & 16,21 & $\begin{array}{c}1980-2120 \\
\text { oven-dried } \\
\text { samples at } 105^{\circ} \mathrm{C}\end{array}$ & - & - & - & $\begin{array}{l}0.833-1.010\left(\lambda^{*} \text { at }\right. \\
\mathrm{Sr}=0) 1.369-1.820 \\
\left(\lambda^{*} \text { at } \mathrm{Sr}=1\right) \mathrm{HFM}\end{array}$ & - & - \\
\hline & Allison \& Hall (2010) & 25 & 1900 & - & $\begin{array}{l}\text { 14.34 Wet cup } \\
\text { method }\end{array}$ & 868 Calculated & 0.643 HFM & - & - \\
\hline & Zhang Lei et al. (2018) & 32 & $\begin{array}{c}1500-2100 \\
\text { oven-dried } \\
\text { samples at } 105^{\circ} \mathrm{C}\end{array}$ & $\begin{array}{c}\text { 1.3-4.6 Saturated } \\
\text { salts solution } \\
\text { method }\end{array}$ & - & - & $\begin{array}{l}\text { 0.5228-0.9308 Hot } \\
\text { disk Apparatus }\end{array}$ & - & - \\
\hline \multirow{2}{*}{$\begin{array}{l}\text { Constructive } \\
\text { Technique }\end{array}$} & \multirow{2}{*}{ Authors } & \multirow{2}{*}{ Ref. } & \multicolumn{7}{|c|}{ Measured Hygrothermal Properties } \\
\hline & & & $\begin{array}{l}\text { Dry Density } \rho \\
{\left[\mathrm{kg} \mathrm{m}^{-3}\right]}\end{array}$ & EMC Range [\%] & $\begin{array}{c}\text { Water Vapour } \\
\text { Resistance Factor } \\
\mu[-]\end{array}$ & $\begin{array}{l}\text { Specific Heat } \\
\text { Capacity c } \\
{\left[\mathrm{Jg}^{-1} \mathbf{K}^{-1}\right]}\end{array}$ & $\begin{array}{c}\text { Thermal } \\
\text { Conductivity } \lambda \\
{\left[\mathrm{W} \mathrm{m}^{-1} \mathrm{~K}^{-1}\right]}\end{array}$ & $\begin{array}{l}\text { Thermal Effusivity e } \\
{\left[\mathrm{J} \mathrm{m}^{-2} \mathrm{~K}^{-1} \mathrm{~s}^{-1 / 2}\right]}\end{array}$ & $\begin{array}{l}\text { Thermal Diffusivity a } \\
{\left[\mathrm{m}^{2} \mathrm{~s}^{-1}\right]}\end{array}$ \\
\hline \multirow[t]{5}{*}{$\begin{array}{c}\text { Rammed } \\
\text { Earth/Compressed } \\
\text { Earth Block }\end{array}$} & $\begin{array}{l}\text { Suárez-Domínguez et al. } \\
\qquad(2018)\end{array}$ & 26 & $1780-1910$ & - & - & - & $\begin{array}{l}0.786-0.846 \text { Hot } \\
\text { wire method }\end{array}$ & - & - \\
\hline & $\begin{array}{l}\text { Barbeta Solà \& Massó Ros } \\
\text { (2015) }\end{array}$ & 33,34 & $1340-2080$ & - & - & - & $0.19-1.35 \mathrm{HFM}$ & - & - \\
\hline & Soudani et al. (2017) & 35 & 1730 & - & - & 648 & 0.6 (dry)-2.4 (wet) & $\begin{array}{c}820 \text { (dry)-1158 (10\% } \\
\text { wet) }\end{array}$ & $5.410^{-7}-6.410^{-7}$ \\
\hline & Porter et al. (2018) & 27 & $2064-2138$ & - & - & $\begin{array}{l}\text { 1321-1832 Hot plate } \\
\text { method }\end{array}$ & - & - & - \\
\hline & Stone \& Katunsky (2015) & 37 & - & - & - & - & - & $\begin{array}{l}529.2-833.9 \\
\text { Calculated }\end{array}$ & $\begin{array}{l}4.610^{-7}-7.310^{-7} \\
\quad \text { Calculated }\end{array}$ \\
\hline \multirow{4}{*}{ Light earth } & Cobreros et al. (2018) & 36 & - & - & - & - & $0.09-0.35$ GHP & - & - \\
\hline & Wieser et al. (2018) & 22 & 616-1089 & - & - & - & $0.121-0.19$ HFM & - & - \\
\hline & Minke (2006) & 4 & 300-700 & - & - & 1000 & $0.07-0.20$ & - & - \\
\hline & Volhard (2016) & 12 & $300-1200$ & - & $2-5$ & 1000-1300 & $0.1-0.47$ & 200-1083 & - \\
\hline
\end{tabular}


Table 3. Cont.

\begin{tabular}{|c|c|c|c|c|c|c|c|c|c|}
\hline \multirow{2}{*}{$\begin{array}{l}\text { Constructive } \\
\text { Technique }\end{array}$} & \multirow{2}{*}{ Authors } & \multirow{2}{*}{ Ref. } & \multicolumn{7}{|c|}{ Measured Hygrothermal Properties } \\
\hline & & & $\begin{array}{l}\text { Dry Density } \rho \\
\quad\left[\mathrm{kg} \mathrm{m}^{-3}\right]\end{array}$ & EMC Range [\%] & $\begin{array}{c}\text { Water Vapour } \\
\text { Resistance Factor } \\
\mu[-]\end{array}$ & $\begin{array}{c}\text { Specific Heat } \\
\text { Capacity c } \\
{\left[\mathrm{J} \mathrm{kg}^{-1} \mathrm{~K}^{-1}\right]}\end{array}$ & $\begin{array}{c}\text { Thermal } \\
\text { Conductivity } \lambda \\
{\left[\mathrm{W} \mathrm{m}^{-1} \mathrm{~K}^{-1}\right]}\end{array}$ & $\begin{array}{l}\text { Thermal Effusivity e } \\
{\left[\mathrm{J} \mathrm{m}^{-2} \mathrm{~K}^{-1} \mathrm{~s}^{-1 / 2}\right]}\end{array}$ & $\begin{array}{c}\text { Thermal Diffusivity a } \\
{\left[\mathrm{m}^{2} \mathrm{~s}^{-1}\right]}\end{array}$ \\
\hline \multirow[t]{2}{*}{ Light earth } & Labat, Magniont et al. (2016) & 39 & $241-531$ & $\begin{array}{c}\text { 1.8-12 Climate } \\
\text { chamber and } \\
\text { Saturated Salt } \\
\text { Solutions method }\end{array}$ & $\begin{array}{l}2.9 \text { (wet)-4.8 (dry) } \\
\text { Cup Method }\end{array}$ & - & $0.071-0.120 \mathrm{GHP}$ & - & - \\
\hline & $\begin{array}{l}\text { Niang, Maalouf, } \\
\text { Moussa et al. (2018) }\end{array}$ & 41 & $323-586$ & $\begin{array}{l}\text { 1.5-12.9 Climate } \\
\text { Chamber and } \\
\text { Saturated Salt } \\
\text { Solutions method }\end{array}$ & $\begin{array}{c}1.279-2.499 \text { (wet) } \\
\text { 3.748-7.057 (dry) } \\
\text { Cup Method }\end{array}$ & - & $\begin{array}{c}0.065-0.112 \mathrm{HFM} \\
0.131-0.164 \mathrm{Hot} \\
\text { wire }\end{array}$ & $\begin{array}{l}\text { 140.6-247.3 HFM, } \\
\text { 184-300.1 Hot wire }\end{array}$ & $\begin{array}{c}2.110^{-7}-2.310^{-7} \mathrm{HFM}, \\
3.010^{-7}-4.310^{-7} \mathrm{Hot} \\
\text { wire }\end{array}$ \\
\hline
\end{tabular}

N.B. Thermal conductivity in the table is measured on oven-dried samples, except where specified. Oven-drying temperature is reported in the column of dry density. The symbol $\lambda^{*}$ corresponds to a thermal conductivity which depends on water saturation of the samples. 
Indekeu et al. [37] realize dynamic hygrothermal measurements of rammed earth material samples with a sorption isotherm, stabilizing at an uptaken volumetric moisture content $\Delta w=9 \mathrm{~kg} \mathrm{~m}^{-3}$. Sorption isotherm curves for stabilized rammed earth are shown by Hall \& Allison [23] for three different mix designs: maximum moisture content at higher humidities for these materials goes from 30 to $50 \mathrm{~kg} \mathrm{~m}^{-3}$. In 2010, the same authors work on the base material of a rammed earth test box, finding a water content at $80 \% \mathrm{RH}$ of $61.5 \mathrm{~kg} \mathrm{~m}^{-3}$ [38]. Zhang Lei et al. [16] show EMC as a function of relative humidity, finding values from $1.3 \%$ to $4.6 \%$.

Similar EMC from Sorption isotherms for lighter earth materials are found by Labat, Magniont et al. [20], with values ranging from 1.8\% to $12 \%$ and by Niang, Maalouf, Moussa et al. [22], with values from $1.5 \%$ up to $12.9 \%$ for higher humidities.

\subsection{Water Vapour Permeability/Water Vapour Resistance Factor}

Cagnon et al. [17] present interesting values of water vapour permeability $\pi$ and water vapour diffusion resistance factor $\mu$ of extruded earth bricks, obtained by the dry cup and wet cup method: the water vapour diffusion resistance factor $\mu$ results of the first analysis range from 7 to 19 (corresponding $\pi=1.0$ to $\left.2.7 \times 10^{-11} \mathrm{~kg} \mathrm{~m}^{-1} \mathrm{~s}^{-1} \mathrm{~Pa}^{-1}\right)$ are higher compared to those of the wet one, which range from 3 to 7 (corresponding $\pi$ from 2.7 to $6.2 \times 10^{-11} \mathrm{~kg} \mathrm{~m}^{-1} \mathrm{~s}^{-1} \mathrm{~Pa}^{-1}$ ), as mentioned by other authors. Medjelekh et al. [19] use an analytic procedure to find vapour permeability as a function of the water content, with the higher value equal to $1.5 \mathrm{E}-10 \mathrm{~kg} \mathrm{~m}^{-1} \mathrm{~s}^{-1} \mathrm{~Pa}^{-1}$. Allam et al. [21] find water vapour permeability for earth brick samples corresponding to $1.45 \times 10^{-10} \mathrm{~kg} \mathrm{~m}^{-1} \mathrm{~s}^{-1} \mathrm{~Pa}^{-1}$ up to $1.8 \times 10^{-10} \mathrm{~kg} \mathrm{~m}^{-1} \mathrm{~s}^{-1} \mathrm{~Pa}^{-1}$.

Hall and Allison [23] show lower (1.4 g) and upper (7.9 g) range of mass transfer rates in a vapour permeability test for three samples of cement stabilized rammed earth, corresponding to vapour permeance values from $1.56 \times 10^{-10}$ to $4.79 \times 10^{-10} \mathrm{~kg} \mathrm{~m}^{-1} \mathrm{~s}^{-1} \mathrm{~Pa}^{-1}$, calculated as the ratio between water vapour flow rate and specimen inflow surface area for the water vapour pressure difference across the specimen. The authors also show the hygroscopic moisture storage function for the samples, going from 19.19 to $31.59 \mathrm{~kg} \mathrm{~m}^{-3}$. In 2010, the same authors calculate the vapour diffusion resistance factor of a different rammed earth sample, finding a value of 14.34 [37].

Volhard [11] presents average values of water vapour diffusion resistance factor, equal to 2-5 for light earth, 3-5 for straw-clay mixtures and 5-10 for monolithic earth. Labat, Magniont et al. [20] find similar values of water vapour diffusion factor for straw-clay mixtures: 2.9 (with the wet cup method) and 4.8 (with the dry cup method). Finally, for the light earth Typha composites, Niang, Maalouf, Moussa et al. [22] find values ranging between 1.279-2.499 with the wet cup method and 3.249-7.057 with the dry cup one.

\subsection{Moisture Buffering Value (Mbv)}

Few authors propose the assessment of moisture buffering value (MBV), which is an important parameter describing the moisture uptake/release capacity by the material [31]. Liuzzi et al. [25] characterize different clay composites for interior coatings in order to find the material with higher buffering capacity, finding values ranging from 1.23 to $1.88 \mathrm{~g} \mathrm{~m}^{-2} \% \mathrm{RH}^{-1}$. Niang et al. [22] determine MBV of typha-clay light earth composites, confirming that the presence of natural fibers can broader the moisture buffering effect of raw earth materials, reaching values from 3.23 to $4.30 \mathrm{~g} \mathrm{~m}^{-2} \% \mathrm{RH}^{-1}$ and creating, de facto, an excellent moisture regulator.

\subsection{Specific Heat Capacity}

Dry heat capacity is often performed by a calorimeter of differential type, as in Medjelekh et al. [19], finding values between $817.6\left(40^{\circ} \mathrm{C}\right)$ and $877.6\left(100^{\circ} \mathrm{C}\right) \mathrm{J} \mathrm{kg}^{-1} \mathrm{~K}^{-1}$. Cagnon et al. [17] assess extruded earth bricks heat capacity both by calorimeter and Desprotherm, finding values from 900 to $960 \mathrm{~J} \mathrm{~kg}^{-1} \mathrm{~K}^{-1}$ for the first one and from 950 to $1030 \mathrm{~J} \mathrm{~kg}^{-1} \mathrm{~K}^{-1}$ for the second one. El Fgaier et al. [32] measure heat capacity by the indirect method, finding values lower than the reference literature ones: 
from 545 to $662 \mathrm{~J} \mathrm{~kg}^{-1} \mathrm{~K}^{-1}$. Allam et al. [21] present different specific heat capacity for dry earth brick samples $\left(750 \mathrm{~J} \mathrm{~kg}^{-1} \mathrm{~K}^{-1}\right)$ and wet ones $\left(1200 \mathrm{~J} \mathrm{~kg}^{-1} \mathrm{~K}^{-1}\right)$.

Higher values of heat capacity can be found for rammed earth samples, as in Indekeu et al. [37], which find $939 \mathrm{~J} \mathrm{~kg}^{-1} \mathrm{~K}^{-1}$ on a sample conditioned at $25^{\circ} \mathrm{C}$ and $57.6 \% \mathrm{RH}$. In Hall and Allison [33], we found Volumetric heat capacity for three cement stabilized rammed earth samples, all averaging from 1.719 to $1.754 \mathrm{MJ} \mathrm{m}^{-3} \mathrm{~K}^{-1}$. In 2010, the authors repeat similar measure on different material, finding a specific heat capacity of $868 \mathrm{~J} \mathrm{~kg}^{-1} \mathrm{~K}^{-1}$ [38]. Porter et al. [39] stabilise rammed earth sample both with $6 \%$ cement and with $6 \%$ cement plus $20 \%$ of crumbed rubber, finding a decrease in density (from 2138 to $2064 \mathrm{~kg} \mathrm{~m}^{-3}$ ) and an increase in specific heat capacity (from 1321 of the first sample, to $1832 \mathrm{~J} \mathrm{~kg}^{-1} \mathrm{~K}^{-1}$ of the sample with rubber).

Volhard [11] presents specific heat capacities from 1000 to $1300 \mathrm{~J} \mathrm{~kg}^{-1} \mathrm{~K}^{-1}$ for lighter earth materials.

\subsection{Thermal Conductivity}

Medjelekh et al. [19] measured different thermal conductivities varying the humidity of the samples, by transient measurements. They find conductivities ranging from $0.77 \mathrm{~W} \mathrm{~m}^{-1-} \mathrm{K}^{-1}$ to $0.95 \mathrm{~W} \mathrm{~m}^{-1-} \mathrm{K}^{-1}$ for each humidity stabilization level of the sorption-desorption isotherms test. Cagnon et al. [17] determine thermal conductivity dependence on saturation degree of extruded earth bricks, confirming Liuzzi [25] observation about the linear correlation at slightly low degree of saturation, while results on higher degrees are more scattered. Thermal conductivity is detected by guarded hot plate and mostly confirmed by the Desprotherm apparatus, with $\lambda_{\text {dry }}$ ranging from $0.47 \mathrm{~W} \mathrm{~m}^{-1-} \mathrm{K}^{-1}$ to $0.59 \mathrm{~W} \mathrm{~m}^{-1-} \mathrm{K}^{-1}$ for the first method and $0.40 \mathrm{~W} \mathrm{~m}^{-1-} \mathrm{K}^{-1}$ to $0.69 \mathrm{~W} \mathrm{~m}^{-1-} \mathrm{K}^{-1}$ for the second one. Laborel-Préneron et al. [40] compares dry thermal conductivity of raw earth with its $6 \%$ barley straw- stabilized version, finding out a decrease from $0.57 \mathrm{~W} \mathrm{~m}^{-1-} \mathrm{K}^{-1}$ to $0.14 \mathrm{~W} \mathrm{~m}^{-1-} \mathrm{K}^{-1}$ caused by the addition of natural fibers, and consequent decrease in dry density (from 1075 to $1995 \mathrm{~kg} \mathrm{~m}^{-3}$ ). El Fgaier et al. [32] work on three extruded raw earth bricks, produced by brickworks in France and composed by fine aggregates: they measure homogeneous $\lambda$-values around $0.9 \mathrm{~W} \mathrm{~m}^{-1-} \mathrm{K}^{-1}$. Gomaa et al. [41] present an interesting work on 3d-printed cob elements with $2 \%$ straw and cohesive soil, realized as solid elements, with two cavities and with one single straw-filled cavity: these specimens are tested in a heat flow meter and conductivities ranging from $0.32 \mathrm{~W} \mathrm{~m}^{-1-} \mathrm{K}^{-1}$ to $0.48 \mathrm{~W} \mathrm{~m}^{-1-} \mathrm{K}^{-1}$ are found, corresponding to dry densities from $1283.7 \mathrm{~kg} \mathrm{~m}^{-3}$ to $1780.3 \mathrm{~kg} \mathrm{~m}^{-3}$. In the same work the authors report some materials developed inside the CobBauge Project 2018, where some English and French cohesive soils, suitable for cob constructions, have been mixed with hemp shiv, chopped reed and straw, with increasing proportions of $0 \%, 2 \%, 4 \%$ and $8 \%$ of the dry weight of soil. The densities are lower than the ones of the $3 \mathrm{~d}$-printing experiment, from $1038.7 \mathrm{~kg} \mathrm{~m}^{-3}$ to $1832.3 \mathrm{~kg} \mathrm{~m}^{-3}$, and conductivities from $0.25 \mathrm{~W} \mathrm{~m}^{-1-} \mathrm{K}^{-1}$ to $0.84 \mathrm{~W} \mathrm{~m}^{-1-} \mathrm{K}^{-1}$. A transient hot-wire method is used in the experimental characterization campaign of Ashour et al. [15] and thermal conductivity for $0 \%, 1 \%$ and $3 \%$ fiber-tabilized samples is found to decrease from $0.96 \mathrm{~W} \mathrm{~m}^{-1-} \mathrm{K}^{-1}$ to $0.31 \mathrm{~W} \mathrm{~m}^{-1-} \mathrm{K}^{-1}$, while the addition of cement and gypsum causes a $\lambda$-increase up to $51.6 \%$ with only fibers-stabilized samples. Millogo et al. [42] measure the change of thermal conductivity modifying the amount of Hibiscus cannibinus fibers inside pressed adobe blocks, obtained by mixing a cohesive soil with increasing percentages of two-lengths Hibiscus fibers (from $0 \%$ to $0.8 \%$ ). The measure is done with a hot wire probe, and the thermal conductivity is observed to decrease from $9 \%$ for the lower percentage of the 3 $\mathrm{cm}$-long fibers to $20 \%$ for the higher percentage of the $6 \mathrm{~cm}$-long fibers. In any case, in this work thermal conductivity never goes down of $1.30 \mathrm{~W} \mathrm{~m}^{-1-} \mathrm{K}^{-1}$. Ouedraogo et al. [43] confirm that the addition of fonio straw to adobes cause a decrease of $67 \%$ in thermal conductivity, from $0.37-1.05 \mathrm{~W} \mathrm{~m}^{-1-} \mathrm{K}^{-1}$. Allam et al. [21] present the variation of thermal conductivity between dry $\left(0.38-0.43 \mathrm{~W} \mathrm{~m}^{-1-} \mathrm{K}^{-1}\right)$ and wet $\left(0.55-0.62 \mathrm{~W} \mathrm{~m}^{-1-} \mathrm{K}^{-1}\right)$ clay bricks. Giroudon, Laborel-Préneron et al. [44] assess thermal conductivity improvement of plastic earth mixtures using barley and lavender straw, finding values from 0.155 to $0.471 \mathrm{~W} \mathrm{~m}^{-1-} \mathrm{K}^{-1}$, with lower values for barley straw, more porous compared to lavender straw. 
Indekeu et al. [37] assess rammed earth material samples thermal conductivity, as $\lambda=1.1 \mathrm{~W} \mathrm{~m}^{-1-} \mathrm{K}^{-1}$. Hall and Allison [23] characterize 3 different cement stabilized rammed earth samples, finding conductivity values at a Saturation rate of $0 \%$ from $0.833 \mathrm{~W} \mathrm{~m}^{-1-} \mathrm{K}^{-1}$ to $1.010 \mathrm{~W} \mathrm{~m}^{-1-} \mathrm{K}^{-1}$, and conductivity at $\mathrm{Sr}=100 \%$ from $1.369 \mathrm{~W} \mathrm{~m}^{-1-} \mathrm{K}^{-1}$ to $1.820 \mathrm{~W} \mathrm{~m}^{-1-} \mathrm{K}^{-1}$. In 2010, the same authors implement a hygrothermal analysis on a stabilised rammed earth test building, finding a lower dry state thermal conductivity $\left(0.643 \mathrm{~W} \mathrm{~m}^{-1-} \mathrm{K}^{-1}\right)$, with a lower dry density of $1900 \mathrm{~kg} \mathrm{~m}^{-3}$ [38]. In Porter et al. [39], the addition of $20 \%$ crumb rubber in the rammed earth mix causes a $20 \%$ slower temperature increase compared to the not additivated one. Zhang Lei et al. [16] work on increasing dry density of compressed earth bricks, from $1500 \mathrm{~kg} \mathrm{~m}^{-3}$ to $2100 \mathrm{~kg} \mathrm{~m}^{-3}$, finding increasing values of thermal conductivity from $0.5228 \mathrm{~W} \mathrm{~m}^{-1-} \mathrm{K}^{-1}$ to $0.9308 \mathrm{~W} \mathrm{~m}^{-1-} \mathrm{K}^{-1}$. Suárez-Domínguez et al. [45] work on soil-cement mixtures using a coarse Mexican soil blended with $16 \%$ of cement, with $100 \mathrm{mg}$ for each $\mathrm{kg}$ of mix, and $1 \%$ of nopal mucilage, finding higher conductivity $(\lambda=0.846)$ compared to the not stabilized mix $\left(\lambda=0.786 \mathrm{~W} \mathrm{~m}^{-1-} \mathrm{K}^{-1}\right)$. G. Barbeta Solà \& F.X. Massó Ros [46,47] use natural aggregates to improve thermal performance of rammed earth walls, as black cork shavings or expanded clay, triturated almond shell and olive stone, in percentages from $15 \%$ to $40 \%$, and mixing them with different amount of water and cementitious stabilizers (5\% and $8 \%$ of Portland Cement): so they obtain reduction in thermal conductivity up to $66.70 \%$, with optimal aggregate percentage around $30 \%$ in dry weight, reaching conductivities of $0.19 \mathrm{~W} \mathrm{~m}^{-1-} \mathrm{K}^{-1}$. Soudani et al. [48] assess the energy performance of rammed earth walls of a house in Rhône-Alpes region, France: they assess thermal conductivity right after manufacturing as equal to $2.4 \mathrm{~W} \mathrm{~m}^{-1-} \mathrm{K}^{-1}$, then after a drying period of $48 \mathrm{~h}$ $\left(2.1 \mathrm{~W} \mathrm{~m}^{-1-} \mathrm{K}^{-1}\right)$ and finally when totally dried $\left(0.6 \mathrm{~W} \mathrm{~m}^{-1-} \mathrm{K}^{-1}\right)$.

Cobrero et al. [49] present the results of thermal conductivity measurements on prefabricated raw earth panels using clayey soil, sand, lime, flying ashes and increasing amount of barley straw, ranging from $0.09 \mathrm{~W} \mathrm{~m}^{-1-} \mathrm{K}^{-1}$ to $0.35 \mathrm{~W} \mathrm{~m}^{-1-} \mathrm{K}^{-1}$, but they do not report the densities of these mixes. Wieser et al. [36] work on light earth mixes of a silty clayey soil used in combination with Gramineae straw, rice husk, and wood chips, finding thermal conductivities of $0.121 \mathrm{~W} \mathrm{~m}^{-1-} \mathrm{K}^{-1}-0.124 \mathrm{~W} \mathrm{~m}^{-1-} \mathrm{K}^{-1}$ for the lighter straw mixes, and $0.19 \mathrm{~W} \mathrm{~m}^{-1-} \mathrm{K}^{-1}$ and $0.178 \mathrm{~W} \mathrm{~m}^{-1-} \mathrm{K}^{-1}$ for the mixes with rice husk and wood chips. Minke [3] shows some alternatives on lightweight loam mixes (the name he uses for light earth mixes) using natural fibers (straw) and recycled ones (cork shavings, wood chips) or mineral aggregates like expanded clay, with thermal conductivities values from $0.07 \mathrm{~W} \mathrm{~m}^{-1-} \mathrm{K}^{-1}$ to $0.20 \mathrm{~W} \mathrm{~m}^{-1-} \mathrm{K}^{-1}$. In 2006, Volhard [11] compares light earth and straw-clay thermal properties: for the light earth material, with bulk density ranging from $300-1200 \mathrm{~kg} \mathrm{~m}^{-3}$, he indicates thermal conductivities from $0.1 \mathrm{~W} \mathrm{~m}^{-1-} \mathrm{K}^{-1}$ to $0.47 \mathrm{~W} \mathrm{~m}^{-1-} \mathrm{K}^{-1}$, for the straw-clay, a denser material $\left(1400-1600 \mathrm{~kg} \mathrm{~m}^{-3}\right)$ the expected conductivity is in the range from $0.59 \mathrm{~W} \mathrm{~m}^{-1-} \mathrm{K}^{-1}$ to $0.73 \mathrm{~W} \mathrm{~m}^{-1-} \mathrm{K}^{-1}$. Labat, Magniont et al. [20] find thermal conductivities increasing from 0.071 to $0.12 \mathrm{~W} \mathrm{~m}^{-1-} \mathrm{K}^{-1}$ for increasing densities from 241 to $531 \mathrm{~kg} \mathrm{~m}^{-3}$. Niang, Maalouf, Moussa et al. [22] assess thermal conductivity for Typha-clay light earth composites through the heat flow meter and the hot wire method, finding lower values for the HFM $\left(0.065-0.112 \mathrm{~W} \mathrm{~m}^{-1-} \mathrm{K}^{-1}\right)$ compared to the hot-wire $\left(0.131-0.164 \mathrm{~W} \mathrm{~m}^{-1-} \mathrm{K}^{-1}\right)$.

\subsection{Thermal Effusivity and Diffusivity}

Cagnon et al. [17] measure high thermal effusivity for all the five extruded earth bricks, all approximately equal to $900-1100 \mathrm{~J} \mathrm{~m}^{-2} \mathrm{~K}^{-1} \mathrm{~s}^{-1 / 2}$. Thermal effusivity can be found also by the theoretical way, knowing $c, \lambda$ and material thickness: F. El Fgaier et al. [32] find values ranging from $936.49 \mathrm{~J} \mathrm{~m}^{-2} \mathrm{~K}^{-1} \mathrm{~s}^{-1 / 2}$ to $1176.95 \mathrm{~J} \mathrm{~m}^{-2} \mathrm{~K}^{-1} \mathrm{~s}^{-1 / 2}$, correspondent diffusivity values range from $5.72 \times 10^{-7} \mathrm{~m}^{2} \mathrm{~s}^{-1}$ to $9.23 \times 10^{-7} \mathrm{~m}^{2} \mathrm{~s}^{-1}$. As known, thermal effusivity can be used to represent thermal inertia of a material [50] and can be estimated through an admittance procedure implemented by a finite element analysis: in this way, using thermal conductivities provided by two standards, Stone and Katunsky find thermal effusivities lower then experimentally measured ones, from $529.2 \mathrm{~J} \mathrm{~m}^{-2} \mathrm{~K}^{-1} \mathrm{~s}^{-1 / 2}$ to $833.9 \mathrm{~J} \mathrm{~m}^{-2} \mathrm{~K}^{-1} \mathrm{~s}^{-1 / 2}$, and diffusivity values from $4.6 \times 10^{-7} \mathrm{~m}^{2} \mathrm{~s}^{-1}$ to 
$7.3 \times 10^{-7} \mathrm{~m}^{2} \mathrm{~s}^{-1}$. Soudani et al. [48] indicates thermal diffusivity of dry earth and wet earth (with a mass water content of $10 \%$ ) as equal to $5.4 \times 10^{-7} \mathrm{~m}^{2} \mathrm{~s}^{-1}$ (dry) and $6.4 \times 10^{-7} \mathrm{~m}^{2} \mathrm{~s}^{-1}$ (wet), and effusivity equal to $820 \mathrm{~J} \mathrm{~m}^{-2} \mathrm{~K}^{-1} \mathrm{~s}^{-1 / 2}$ and $1158 \mathrm{~J} \mathrm{~m}^{-2} \mathrm{~K}^{-1} \mathrm{~s}^{-1 / 2}$.

Volhard [11] reports thermal effusivity for light earth materials from $200 \mathrm{~J} \mathrm{~m}^{-2} \mathrm{~K}^{-1} \mathrm{~s}^{-1 / 2}$ to $1083 \mathrm{~J} \mathrm{~m}^{-2} \mathrm{~K}^{-1} \mathrm{~s}^{-1 / 2}$. For the light earth material obtained by mixing Typha fiber and clay, Niang, Maalouf, Moussa et al. [22] find thermal effusivity from 140.6 to 300.1 and thermal diffusivity from $2.1 \times 10^{-7}$ to $4.3 \times 10^{-7} \mathrm{~m}^{2} \mathrm{~s}^{-1}$.

\section{Conclusions and Final Remarks}

This paper presented a brief review of the main thermal and hygroscopic properties of raw earth materials and current assessment methods and performances. Raw earth materials can be categorized in many ways, including a classification based on the manufacturing process corresponding to the different main techniques: in this paper we use this classification because mixing water content and usual soil textures for each technique have a strong influence on the final consistency of the material (i.e., the characteristic of the porous network of raw earth materials), distinguishing techniques which use plastic raw earth to be moulded (adobe, cob, extruded bricks), humid raw earth to be dynamically or statically compacted (rammed earth, compressed earth blocks) and finally clay slurry/slip to bond together natural fibers or mineral aggregates for insulating purposes (light earth, straw-clay) [51,52]

Due to the not perfect connections between the different constituents of soils and mixtures, all raw earth materials present a porous network which enables gas and liquid to flow, in a way that raw earth become a hygroscopic massive material where heat and mass transfers (of water vapour) and phase changes happen (like a natural PCM) [53]. As we saw, raw earth composites have a high thermal effusivity (which means high thermal inertia which enhances thermal comfort and energy efficiency of dwellings). Moreover, earth possesses a low water vapour diffusion resistance, and a highly hygroscopic behaviour: so raw earth materials have both good buffering capacities and hygrothermal inertia properties, and this is the reason why earth buildings are known for keeping interior temperatures almost constant and regulating indoor relative humidity.

From the comparison between the techniques using fibers in the mix (adobe, cob, wattle, and daub, light earth) and the one not using them (rammed earth, compressed earth blocks) emerges that the addition of fibres, due to their biochemical composition (presence of almost crystalline cellulose and hemicelluloses, which are hydrophilic compounds), in association with the clay matrix, increases the absorption of water and is accompanied by a significant increase in porosity due to the air trapped during mixing and a decrease of thermal conductivity. In the following graph (Figure 1) thermal conductivity and mass density are plotted in order to compare the results from various authors: even if the three types of materials give scattered $\lambda$-values, the ones of rammed earth/compressed earth block and light earth groups seem to be more homogeneous compared to the adobe/cob/wattle and daub one.

From the comparison between the EMC values for several relative humidity and temperature conditions, it is possible to state that denser raw earth materials as adobe, cob, wattle, and daub, extruded bricks (plastic mixtures) and rammed earth, compressed earth block (humid mixtures) reach lower EMC values compared to light earth materials, which have higher moisture storage properties because of the higher amount of fibers contained and consequent higher porosity. The protocol followed to assess moisture storage is not unified, so different \%RH is used between the authors. Concerning the evaluation of water vapour resistance factor, whose assessment is obtained from the evaluation of water vapour permeability by the dry or wet cup method, the values for all the techniques are quite scattered, even if all the authors report that the dry cup method gives slightly higher values compared to wet cup one. Finally, the assessment of moisture buffering value and the consequent evaluation of the effective moisture penetration depth confirm that raw earth materials can buffer environmental moisture even with low thicknesses. 


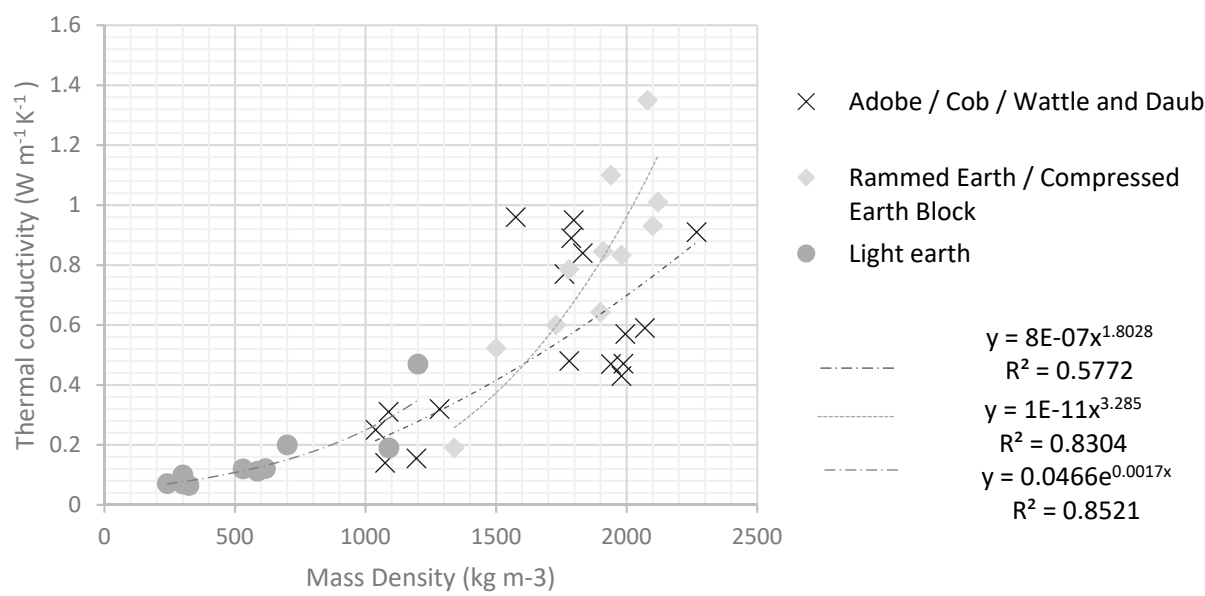

Figure 1. Thermal conductivity vs Mass density for different raw earth materials.

From the literature review emerges the lack in the normalization of experimental protocols for the assessment of the hygrothermal performance of raw earth materials: this means that properties assessed at different boundary conditions could not be immediately comparable. Great variability exists in many measurement protocols: for instance, for dry mass assessment, there is no agreement despite the importance of this parameter to determine key material characteristics such as adsorption-desorption capacity, dry density, thermal conductivity, heat capacity, strength, and stiffness. Likewise, moisture dependant thermal conductivity is assessed only by some authors and following different laboratory protocols, complicating the comparison between measurements. The uncertainty on these two parameters has big influence on the assessment of derived parameters as thermal diffusivity and effusivity, which are often calculated instead of being measured. Furthermore, the comparison of the results could also be distorted by the variability of the earth-material that is a "heterogeneous" substance (in the same quarry, earth taken from different areas or from different layers may have different characteristics). Obviously, the homogeneity of laboratory samples may not reflect field conditions.

Another big restriction for the assessment of hygrothermal characteristics is the high cost of the equipment needed to realize some tests as the heat capacity and thermal diffusivity/effusivity ones. This restraint prevents from the assessment of properties which could demonstrate the good performance of earth building compared to other building materials like wood and concrete, respectively in buffering temperature variations (for the low values of thermal diffusivity) and store heat efficiently (for earth's high values of thermal effusivity). An approach to overcome this problem is the one using hygrothermal simulation models to be confirmed by on-site hygrometric and thermal measurements in experimental test box, in order to assess the final performance of a real earth building: this kind of approach has been used recently by Allison et Hall [38] and Beckett et al. [54] to investigate, respectively, hygrothermal, and thermal behaviour in rammed earth houses in different climates. Measurements made on a building scale are still very limited, and even when field data is available, accurate monitoring of environmental actions is often lacking. The protocols for the determination of in situ measurements must, therefore, be improved and standardized.

Finally, concerning the first two groups of techniques (which are usually adopted for load-bearing structures), we also focused on the use of natural fibers, mineral or recycled aggregates which are currently being implemented by many authors in combination with soil in order to improve the insulation properties of raw earth for winter thermal performance. Only few studies focus on the thermal improvement of raw earth used as a load-bearing material, and this could cause an issue because the optimization for hygrothermal purposes could design a raw earth mix which is not enough resistant (in terms of compressive strength and durability) for building purposes.

Even if the performance-assessment procedures are not fully standardised yet and the results are consequently difficult to compare, hygrothermal performances of earth-based materials seem to be promising for the creation of a new type of building products which can reduce the environmental 
impact of constructions simultaneously creating comfortable and efficient spaces. In pursuance of this, raw earth materials must be considered as systems developing multifunctional performances, where the material can serve structural, hygrothermal, and durability purposes without neglecting the sustainable effects of using passive strategies based on the use of a natural, low-processed, and reusable materials.

Author Contributions: Conceptualization, G.G., R.C. and F.N.; methodology, G.G., R.C. and F.N.; formal analysis, G.G.; investigation, G.G. and R.C.; resources, G.G. and R.C.; data curation, G.G. and R.C.; writing-original draft preparation, G.G.; writing-review and editing, G.G., R.C. and F.N.; visualization, G.G.; supervision, R.C. and F.N.; project administration, G.G., R.C. and F.N.; funding acquisition, R.C. and F.N.

Funding: This work has been financed by the University of Catania within the project "Piano della Ricerca Dipartimentale 2016-2018" of the "Civil Engineering and Architecture Department".

Conflicts of Interest: The authors declare no conflict of interest.

\section{Nomenclature}

$\begin{array}{llllll}\text { wi } & \text { Mixing water content } & \% & \rho & \text { Mass Density } & \mathrm{kg} \mathrm{m}^{-3} \\ \mathrm{Wm} & \text { Moist Weight } & \mathrm{kg} & \lambda & \text { Thermal Conductivity } & \mathrm{W} \mathrm{m}^{-1}-\mathrm{K}^{-1} \\ \text { Wd } & \text { Dry Weight } & \mathrm{kg} & a & \text { Thermal Diffusivity } & \mathrm{m}^{2} \mathrm{~s}^{-1} \\ \mathrm{EMC} & \text { Equilibrium Moisture Content } & \% & \mathrm{~m}_{\text {calo }} & \text { Mass of the calorimeter } & \mathrm{kg} \\ \mu & \text { Water Vapour Resistance Factor } & \mathrm{kg} \mathrm{m}^{-1} \mathrm{~s}^{-1} \mathrm{~Pa}^{-1} & \mathrm{~m}_{\mathrm{w}} & \text { Mass of water } & \mathrm{kg} \\ \pi & \text { Water Vapour Permeability } & - & \mathrm{m}_{\mathrm{mat}} & \text { Mass of the material } & \mathrm{kg} \\ \mathrm{T} & \text { Temperature } & { }^{\circ} \mathrm{C} & e & \text { Thermal Effusivity } & \mathrm{J} \mathrm{m} \mathrm{K}^{-2} \mathrm{~K}^{-1 / 2} \\ \mathrm{RH} & \text { Relative Humidity } & \% & \varphi & \text { thermal phase lag } & \mathrm{s} \\ \mathrm{C} & \text { volumetric heat capacity } & \mathrm{J} \mathrm{m}^{-3} \mathrm{~K}^{-1} & \mathrm{~d} & \text { Thickness } & \mathrm{m}^{-2} \mathrm{RH} \\ \mathrm{c} & \text { Specific Heat Capacity } & \mathrm{J} \mathrm{K}^{-1} \mathrm{~kg}^{-1} & \mathrm{MBV} & \text { Moisture buffering value } & \mathrm{g} \mathrm{m}^{-2} \% \mathrm{RH}\end{array}$

\section{References}

1. International Energy Agency (IEA). 2018 Global Status Report towards a Zero-Emission, Efficient and Resilient Buildings and Construction Sector, Global Alliance for Buildings and Construction (GlobalABC); IEA: Paris, France, 2018.

2. Houben, H.; Guillaud, H. CRATerre: Traité de Construction en Terre; Éditions Parenthèses: Marseille, France, 2006.

3. Minke, G. Building with Earth: Design and Technology of a Sustainable Architecture; Birkhäuser: Berlin, Germany, 2006.

4. Maniatidis, V.; Walker, P. A Review of Rammed Earth Construction; Natural Building Technology Group Department of Architecture Civil Engineering University of Bath: Bath, UK, 2003.

5. Rauch, M. Refined Earth Construction Design with Rammed Earth; Kapfinger, O., Sauer, M., Eds.; Detail: Munich, Germany, 2015.

6. Norma E.080. Diseño y Construccion con Tierra Reforzada 2017; Ministerio de Vivienda, Construcción y Saneamiento: Lima, Peru, 2017.

7. SNZ. New Zealand Standard 4298:1998. In Materials and Workmanship for Earth Buildings 1998; Standards New Zealand: Wellington, New Zealand, 1998.

8. Burroughs, S. Recommendations for the selection, stabilization and compaction of soil for rammed earth wall construction. J. Green Build. 2010, 5, 101-114. [CrossRef]

9. Hall, M.; Djerbib, Y. Rammed earth sample production: Context, recommendations and consistency. Constr. Build. Mater. 2004, 18, 281-286. [CrossRef]

10. Ciancio, D.; Jaquin, P.; Walker, P. Advances on the assessment of soil suitability for rammed earth. Constr. Build. Mater. 2013, 42, 40-47. [CrossRef]

11. Volhard, F. Light Earth Building, A Handbook for Building with Wood and Earth; Birkhauser: Basel, Switzerland, 2016.

12. Bollini, G. Terra Battuta: Tecnica Costruttiva e Recupero. Linee Guida per le Procedure di Intervento; EdicomEdizioni: Milano, Italy, 2013. 
13. Fabbri, A.; Morel, J.C. Earthen materials and constructions. In Nonconventional and Vernacular Construction Materials; Woodhead Publishing Series in Civil and Structural Engineering; Woodhead Publishing: Cambridge, UK, 2013; pp. 273-300.

14. Moevus, M.; Anger, R.; Fontaine, L. Hygro-thermo-mechanical properties of earthen materials for construction: A literature review. In Proceedings of the TERRA 2012, 12th SIACOT PROCEEDINGS, 11th International Conference on the Study and Conservation of Earthen Architectural Heritage, 12th Iberian-American Seminar on Earthen Architecture and Construction, Lima, Peru, 22-27 April 2012.

15. Ashour, T.; Korjenic, A.; Korjenic, S.; Wu, W. Thermal conductivity of unfired earth bricks reinforced by agricultural wastes with cement and gypsum. Energy Build. 2015, 104, 139-146. [CrossRef]

16. Zhang, L.; Yang, L.; Petter Jelle, B.; Wang, Y.; Gustavsen, A. Hygrothermal properties of compressed earthen bricks. Constr. Build. Mater. 2018, 162, 576-583. [CrossRef]

17. Cagnon, H.; Aubert, J.E.; Coutand, M.; Magniont, C. Hygrothermal properties of earth bricks. Energy Build. 2014, 80, 208-217. [CrossRef]

18. Ashour, T.; Korjenic, A.; Korjenic, S. Equilibrium moisture content of earth bricks biocomposites stabilized with cement and gypsum. Cem. Concr. Compos. 2015, 59, 18-25. [CrossRef]

19. Medjelekh, D.; Ulmet, L.; Dubois, F. Characterization of hygrothermal transfers in the unfired earth. Energy Procedia 2017, 139, 487-492. [CrossRef]

20. Labat, M.; Magniont, C.; Oudhof, N.; Aubert, J.E. From the experimental characterization of the hygrothermal properties of straw-clay mixtures to the numerical assessment of their buffering potential. Build. Environ. 2016, 97, 69-81. [CrossRef]

21. Allam, R.; Issaadi, N.; Belarbi, R.; El-Meligy, M.; Altahrany, A. Hygrothermal behavior for a clay brick wall. Heat Mass Transf. 2018, 54, 1579-1591. [CrossRef]

22. Niang, I.; Maalouf, C.; Moussa, T.; Bliard, C.; Samin, E.; Thomachot-Schneider, C.; Lachi, M.; Pron, H.; Mai, T.H.; Gaye, S. Hygrothermal performance of various Typha-clay composite. J. Build. Phys. 2018, 42, 316-335. [CrossRef]

23. Hall, M.; Allinson, D. Analysis of the hygrothermal functional properties of stabilised rammed earth materials. Build. Environ. 2009, 44, 1935-1942. [CrossRef]

24. DIN EN ISO 12271. Hygroskopische Sorptionskurven; DIN EN ISO: Berlin, Germany, 1996.

25. Liuzzi, S.; Hall, M.R.; Stefanizzi, P.; Casey, S.P. Hygrothermal behaviour and relative humidity buffering of unfired and hydrated lime-stabilised clay composites in a Mediterranean climate. Build. Environ. 2013, 61, 82-92. [CrossRef]

26. EN 1015-19:1999. Methods of Test for Mortar for Masonry. Determination of Water Vapour Permeability of Hardened Rendering and Plastering Mortars; EN: Belgium, 1999.

27. Fabbri, A.; Morel, J.C.; Gallipoli, D. Assessing the performance of earth building materials: A review of recent developments. RILEM Tech. Lett. 2018, 3, 46-58. [CrossRef]

28. NF X 30-442. Waste-Laboratory Determination of the Permeability Coefficient of a Saturated Material-Permeability Tests Using an Oedometer at Constant/Variable Hydraulic Load; AFNOR: Sydney, Australia, 2008.

29. BS 3921. British Standard Specification for Clay Bricks, British Standards Institution; BS: London, UK, 1985.

30. EN 1015-18:2003. Methods of Test for Mortar for Masonry_Part 18: Determination of Water Absorption Coefficient due to Capillary Action of Hardened Mortar; Bulgarian Institute for Standardization: Sofia, Bulgaria, 2003.

31. Norden Nordisk Innovation Centre. Nordtest Report Moisture Buffering of Building Materials; Norden Nordisk Innovation Centre BYG DTU: Lyngby, Denmark, 2005.

32. El Fgaier, F.; Lafhaj, Z.; Antczak, E.; Chapiseau, C. Dynamic thermal performance of three types of unfired earth bricks. Appl. Therm. Eng. 2016, 93, 377-383. [CrossRef]

33. Hall, M.; Allinson, D. Assessing the effects of soil grading on the moisture content-dependent thermal conductivity of stabilised rammed earth materials. Appl. Therm. Eng. 2009, 29, 740-747. [CrossRef]

34. ASTM D5334-14. Standard Test Method for Determination of Thermal Conductivity of Soil and Soft Rock by Thermal Needle Probe Procedure; ASTM International: West Conshohocken, PA, USA, 2014; Available online: www.astm.org (accessed on 26 September 2019).

35. ISO-8302. Thermal Insulation. Determination of Steady-State Thermal Resistance and Related Properties. Guarded hot Plate Apparatus; ISO: Geneva, Switzerland, 1991. 
36. Wieser, M.; Onnis, S.; Meli, G. Conductividad Térmica de la tierra alivianada con fibras naturales en paneles de quincha. In Proceedings of the SIACOT 2018 Tierra, Cultura, Hábitat Resiliente y Desarollo Sostenible, 18 Seminário Iberoamericano de Arquitectura y Construcción con Tierra, La Antigua, Guatemala, 22-25 October 2018.

37. Indekeu, M.; Woloszyn, M.; Grillet, A.C.; Soudani, L.; Fabbri, A. Towards Hygrothermal characterization of rammed earth with small-scale dynamic methods. Energy Procedia 2017, 132, 297-302. [CrossRef]

38. Allinson, D.; Hall, M. Hygrothermal analysis of a stabilised rammed earth test building in the UK. Energy Build. 2010, 42, 845-852. [CrossRef]

39. Porter, H.; Blake, J.; Dhami, N.K.; Mukherjee, A. Rammed Earth blocks with improved multifunctional performance. Cem. Concr. Compos. 2018, 92, 36-46. [CrossRef]

40. Laborel-Préneron, A.; Aubert, J.E.; Magniont, C.; Bertron, A. Influence of Straw Content on the Mechanical and Thermal Properties of Bio Based Earth Composites. In Proceedings of the First International Conference on Bio-based Building Materials, Clermont-Ferrand, France, 22-24 June 2015.

41. Gomaa, M.; Carfrae, J.; Goodhew, S.; Jabi, W.; Veliz Reyes, A. Thermal performance exploration of 3D printed cob. Archit. Sci. Rev. 2019, 62, 230-237. [CrossRef]

42. Millogo, Y.; Morel, J.C.; Aubert, J.E.; Ghavami, K. Experimental analysis of Pressed Adobe Blocks reinforced with Hibiscus cannabinus fibers. Constr. Build. Mater. 2014, 52, 71-78. [CrossRef]

43. Ouedraogo, M.; Dao, K.; Millogo, Y.; Aubert, J.; Messan, A.; Seynou, M.; Zerbo, L.; Gomina, M. Thermal and mechanical properties of adobes stabilized with fonio (Digitaria exilis) straw. J. Build. Eng. 2019, 23, $250-258$. [CrossRef]

44. Giroudon, M.; Laborel-Préneron, A.; Aubert, J.E.; Magniont, C. Comparison of barley and lavender straws as bioaggregates in earth bricks. Constr. Build. Mater. 2019, 202, 254-265. [CrossRef]

45. Suárez-Domínguez, E.J.; Aranda-Jiménez, Y.G.; Zúñiga-Leal, C. Resistencia Mecánica Y Conductividad Térmica De Suelo Cemento Plástico Con Adición De Fibra Vegetal. In Proceedings of the SIACOT 2018 Tierra, Cultura, Hábitat Resiliente y Desarollo Sostenible, 18 Seminário Iberoamericano de Arquitecture y Construcción con Tierra, La Antigua, Guatemala, 22-25 October 2018.

46. Barbeta Solà, G.; Massó Ros, F.X. Improved thermal capacity of rammed earth by the inclusion of natural fibres. In Rammed Earth Construction; Beckett, C., Ed.; Taylor Francis Group: London, UK, 2015.

47. Barbeta Solà, G.; Massó Ros, F.X. Thermal improvement of rammed earth buildings by the inclusion of natural cork. In Earthen Architecture: Past, Present and Future; Mileto, C., Vegas, F., Cristini, G.S., Eds.; Taylor Francis Group: London, UK, 2015.

48. Soudani, L.; Woloszyn, M.; Fabbri, A.; Morel, J.C.; Grillet, A.C. Energy evaluation of rammed earth walls using long term in-situ measurements. Sol. Energy 2017, 141, 70-80. [CrossRef]

49. Cobreros, C.; Reyes-Araiza, J.L.; Manzano-Ramírez, A. Paneles Prefabricados Termo-Acústicos a Partir de Paja de Cereal Y Tierra Estabilizada. In Proceedings of the SIACOT 2018 Tierra, Cultura, Hábitat Resiliente y Desarollo Sostenible, 18 Seminário Iberoamericano de Arquitecture y Construcción con Tierra, La Antigua, Guatemala, 22-25 October 2018.

50. Stone, C.; Katunsky, D. Dynamic Thermal Properties of Uninsulated Rammed Earth Envelopes. Int. J. Eng. Inf. Sci. 2015, 10, 103-112. [CrossRef]

51. Goodhew, S.; Griffiths, R. Sustainable earth walls to meet the building regulations. Energy Build. 2005, 37, 451-459. [CrossRef]

52. Saussaye, L.; Boutouil, M.; Baraud, F.; Leleyter, L. Influence of anions on the geotechnical properties of soils treated with hydraulic binders: Individual and coupling effects. Constr. Build. Mater. 2014, 65, 303-309. [CrossRef]

53. Costanzo, V.; Evola, G.; Marletta, L.; Nocera, F. The effectiveness of phase change materials in relation to summer thermal comfort in air-conditioned office buildings. Build. Simul. 2018, 11, 1145-1161. [CrossRef]

54. Beckett, C.T.S.; Cardell-Oliver, R.; Ciancio, D.; Huebner, C. Measured and simulated thermal behaviour in rammed earth houses in a hot-arid climate. Part A: Structural behavior. J. Build. Eng. 2018, 15, $243-251$. [CrossRef]

(C) 2019 by the authors. Licensee MDPI, Basel, Switzerland. This article is an open access article distributed under the terms and conditions of the Creative Commons Attribution (CC BY) license (http://creativecommons.org/licenses/by/4.0/). 